\title{
Trophic ecology of European sardine Sardina pilchardus and European anchovy Engraulis encrasicolus in the Bay of Biscay (north-east Atlantic) inferred from $\delta^{13} \mathrm{C}$ and $\delta^{15} \mathrm{~N}$ values of fish and identified mesozooplanktonic organisms
}

\author{
T. Chouvelon ${ }^{a, *}, 1$, A. Chappuis ${ }^{a, 1}$, P. Bustamante ${ }^{a}$, S. Lefebvre ${ }^{b}$, F. Mornet ${ }^{c}$, G. Guillou $^{a}$, L. Violamer ${ }^{a}$, \\ C. Dupuy ${ }^{a}$ \\ ${ }^{a}$ Littoral Environnement et Sociétés, UMR 7266 CNRS-Université de La Rochelle, 2 rue Olympe de Gouges, F- \\ 17000 La Rochelle Cedex 01, France \\ ${ }^{b}$ Laboratoire d'Océanologie et de Géosciences, UMR 8187 CNRS-Université de Lille 1 sciences et technologies, \\ Station Marine de Wimereux, 28 avenue Foch, F-62930 Wimereux, France \\ ' IFREMER, Laboratoire Ressources Halieutiques de La Rochelle, Place Gaby Coll, F-17087 L'Houmeau, France \\ ${ }^{1}$ These authors contributed equally to this work. \\ *: Corresponding author : Tiphaine Chouvelon, Tel.: + 33546458388 ; email addresses : tiphaine.chouvelon@univ-Ir.fr \\ ; tiphaine.chouvelon@hotmail.fr
}

\begin{abstract}
:
European sardine (Sardina pilchardus) and European anchovy (Engraulis encrasicolus) are two species of economical and ecological significance in the Bay of Biscay (north-east Atlantic). However, the trophic ecology of both species is still poorly known in the area, and more generally, few studies have considered the potential trophic overlap between sardines and anchovies worldwide. This study aims to highlight the trophic links between the mesozooplankton and adults of these two pelagic fish in the Bay of Biscay, through carbon and nitrogen stable isotope analysis (SIA). Mesozooplankton and individuals of sardines and anchovies were collected during one season (spring 2010), over spatially contrasted stations within the study area. First, the potential effect of preservation (ethanol vs. freezing) and of delipidation (by cyclohexane) on mesozooplankton $\delta^{13} \mathrm{C}$ and $\delta^{15} \mathrm{~N}$ values was assessed. Results demonstrated the necessity to correct for the preservation effect and for lipid contents in mesozooplankton for further analyses of sardines' and anchovies' diet through SIA. Next, this study highlighted the interest of working on identified mesozooplanktonic organisms instead of undetermined assemblages when unravelling food sources of planktivorous fish using stable isotopes. The inter-specific variability of isotope values within a planktonic assemblage was effectively high, probably depending on the various feeding behaviours that can occur among mesozooplankton species. Intra-specific variability was also significant and related to the spatial variations of baseline signatures in the area. To investigate the foraging areas and potential diet overlap of $S$. pilchardus and E. encrasicolus, mixing models (SIAR) were applied. Both fish species appeared to feed mainly in the neritic waters of the Bay of Biscay in spring and to select mainly small- to medium-sized copepods (e.g. Acartia sp., Temora sp.). However, E. encrasicolus showed a greater trophic plasticity by foraging more offshore and on a wider range of prey sizes, while $S$. pilchardus seemed more limited to coastal areas and the mesozooplanktonic species of these waters for feeding.
\end{abstract}

Highlights

- Mesozooplankton, sardines and anchovies were analysed for stable isotope values. The preservation method and lipid extraction affected isotopic ratios in plankton. Size-related and spatial variability of values in plankton was highly significant. Mixing models were applied to investigate the trophic overlap of both fish species. Anchovies showed a greater trophic plasticity for both prey size and feeding areas.

Keywords: Plankton preservation ; Plankton delipidation ; Pelagic fish ; Trophic interactions ; Spatial variability ; Isotopic mixing model 


\section{Introduction}

The Bay of Biscay is a highly productive fishing ground, notably for Spanish and French commercial fisheries, due to the high diversity and abundance of marine species (Certain et al., 2008; Spitz and Quéro, 2008; Trenkel et al., 2009). Many species are targeted, such as the European hake (Merluccius merluccius), the common sole (Solea solea), the Norway lobster (Nephrops norvegicus) and the anglerfish (Lophius sp.). European sardine (Sardina pilchardus) and European anchovy (Engraulis encrasicolus) fisheries are also of major importance (e.g., Coiffec et al., 2006; Uriarte et al., 1996). However, no quota exists in this region for sardine yet, despite a known decrease in the number of catch (OSPAR, 2010). On the other hand, a decrease in anchovy stocks during the years 2000 led to the closing of its fishery in 2005. The moratorium ended in 2010, and finally resulted in the instauration of quotas for this species (ICES, 2010ab). In order to prevent adult and juvenile sardines and anchovies from an irreversible decline, a continuous monitoring of these small pelagic fish is necessary. Indeed, sardines and anchovies are not only economically but also ecologically significant, as they are key prey species for a great number of predators such as the common dolphin (Delphinus delphis) or the northern gannet (Morus bassanus) (Certain et al., 2011).

The comprehension of recruitment processes is the cornerstone of a sustainable fishery management, even if it is facing a strong lack of knowledge. One of the aspects that could influence recruitment is the trophic ecology of species. Hence, it is necessary to decipher the connection between resources (mesozooplankton, i.e., zooplankton between 0.2 and $2 \mathrm{~mm}$ ) and planktivorous fish (here, sardines and anchovies) that feed on varying planktonic species but mostly on mesozooplankton and more specifically on copepods (e.g., James, 1988; Plounevez and Champalbert, 1999; Raab et al., 2011; Van der Lingen et al., 2006, 2009). Indeed, even though sardines are morphologically better suited to capture smaller particles than anchovies (e.g., Blaxter and Hunter, 1982; Garrido et al., 2007; James and Findlay, 1989; Van der Lingen, 1994), phytoplankton that can be found in both sardine and anchovy stomachs may be accidental (e.g., Bode et al., 2004; Cunha et al., 2005; Van der Lingen, 1994), and/or does not contribute significantly to the bulk of the dietary carbon in adults (e.g., Nikolioudakis et al., 2012a). However, some authors have suggested that some essential fatty acids originating from phytoplankton could have a strong impact on reproduction success for sardines (Garrido et al., 2008). On the other hand, inadequate sampling and analytical strategies could also be the origin of misleading interpretations stating that these fish can select phytoplankton as a dietary item (James, 1988). Thus, the trophic links within plankton and between plankton and planktivorous fish are not clearly established yet.

One of the problems in the study of pelagic trophic links lies in the difficulty of observing direct interactions between organisms, due to the environment (open water) and the small size of plankton. This latter fact induces another difficulty when studying the stomach contents of planktivorous fish: zooplankton and phytoplankton organisms are sometimes difficult to identify because of their size (James, 1988). These time-consuming analyses may also underestimate some prey species, due to differential digestion rates in fish digestive tracts (Gannon, 1976). Besides, this technique only considers the last food intake, which can be problematic when focusing on long-term feeding behaviours. Therefore, the application of the stable isotopes method offers the possibility of investigating the trophic organisation in a pelagic food web over a relatively long period of time. Indeed, stable isotope ratios generally vary little between those of the primary producers of the local food chain or a prey, and those of the consumers ( $\leq 1 \%$ ) (De Niro and Epstein, 1978; Hobson, 1999). In contrast, consumers are enriched in ${ }^{15} \mathrm{~N}$ relative to their food (between 2.5 and 5\%o) (De Niro and Epstein, 1981; Vanderklift and Ponsard, 2003). Specifically, stable isotope ratios of carbon $\left(\delta^{13} \mathrm{C}\right)$ are thus commonly used as indicators of the feeding area of consumers, as their $\delta^{13} \mathrm{C}$ signatures a priori reflect those of the primary producers at the base of a specific food chain (due to low 
enrichment in ${ }^{13} \mathrm{C}$ along food chains); stable isotope ratios of nitrogen $\left(\delta^{15} \mathrm{~N}\right)$ are more used as indicators of the relative trophic level (Minagawa and Wada, 1984; Montoya, 2007; Peterson and Fry, 1987).

To our knowledge, many studies made relatively large size classes or use great taxon assemblages to explore zooplankton's isotope values (e.g., Bode et al., 2004; Bode and Álvarez-Ossorio, 2004; Schell et al., 1998). However, this can be the origin of confusion and imprecision when analysing trophic interactions within a pelagic food web due to the high variability of $\delta^{13} \mathrm{C}$ and $\delta^{15} \mathrm{~N}$ values in the planktonic compartment, even for similar-sized organisms (e.g., Bode et al., 2007). Moreover, few studies have attempted to evaluate the potential effect of preservation on zooplankton's $\delta^{13} \mathrm{C}$ and $\delta^{15} \mathrm{~N}$ values (e.g., Feuchtmayr and Grey, 2003). For instance, these authors found no significant difference for $\delta^{15} \mathrm{~N}$ values of zooplankton preserved by freezing relative to zooplankton preserved in ethanol, and only a small difference for $\delta^{13} \mathrm{C}$ values. In fact, most studies on the potential effect of the preservation method generally focused on specific tissues of larger organisms (e.g., fish and molluscs). There is generally a trend to an increase of $\delta^{13} \mathrm{C}$ and $\delta^{15} \mathrm{~N}$ values for tissues preserved in ethanol relative to frozen material, notably for fat tissues (Kaehler and Pakhomov, 2001; Sarakinos et al., 2002; Sweeting et al., 2004). Besides this, few studies are available concerning the necessity or not to proceed to delipidation (i.e., lipid extraction) before stable isotopes analysis (SIA) of zooplankton (e.g., Smyntek et al., 2007). Lipids are effectively highly depleted in ${ }^{13} \mathrm{C}$ relative to other tissue components (De Niro and Epstein, 1977), and it is thus important to account for lipids when comparing species or individuals with variable lipid content (Post et al., 2007). In fact, some corrections exist in the literature to deal with the lipid contents of organisms (e.g., Post et al., 2007), and notably for plankton using the $\mathrm{C} / \mathrm{N}$ ratio of bulk samples analysed (e.g., Smyntek et al., 2007). Indeed, for animals, the $\mathrm{C} / \mathrm{N}$ ratio is generally a strong predictor of lipid content (Post et al., 2007). However, these corrections generally do not apply to samples that have been chemically preserved in ethanol or formalin (Post et al., 2007), which are generally the preservation methods used for plankton to allow further work in the laboratory. Indeed, the linear relationship between bulk $\mathrm{C} / \mathrm{N}$ and $\Delta \delta^{13} \mathrm{C}\left(=\delta^{13} \mathrm{C}\right.$ delipidated sample $\left.-\delta^{13} \mathrm{C}_{\text {bulk sample }}\right)$ normally used for mathematical correction may not be linear, due to the previous effects of preservation (Post et al., 2007).

In this context, the purpose of this study is twofold: 1) assessing potential effects of the preservation method (ethanol vs. freezing) and of delipidation (by cyclohexane) on mesozooplankton's stable isotopes values for further correction of values if necessary; 2) determining the links between plankton-eating fish (i.e., sardines and anchovies) and mesozooplankton in the Bay of Biscay, while highlighting potential preferential feeding areas. For these purposes, the SIA of fish and prey samples (i.e., mesozooplanktonic species analysed separately) were performed and mixing models were applied. The latter are a useful tool to assess the proportional contribution of sources in a predator's diet (Parnell et al., 2010; Phillips, 2001).

\section{Materials and methods}

\subsection{Data collection, taxonomic determination and sample preparation}

Mesozooplankton and fish samples were collected in spring 2010 during the PELGAS 2010 survey $\left(25^{\text {th }}\right.$ April $-5^{\text {th }}$ June $)$ conducted by Institut Français de Recherche pour l'Exploitation de la Mer (IFREMER), on the continental shelf to the shelf-edge of the Bay of Biscay. Plankton was collected during the night by vertical trawls of $200 \mu \mathrm{m}$ mesh-size WP2 nets, from 100m depth (or bottom depth for near-shore stations) to the surface. 
For this study, 13 stations were selected, along five transects, from the north to the south of the Bay of Biscay and from the coastline $(\mathrm{C})$ to the continental slope (SI) including stations over the continental shelf (Sh) (Fig. 1). For each station, two mesozooplankton samples were collected together and concentrated on a $200 \mu \mathrm{m}$ mesh for subsequent stable isotope analysis: one was slightly rinsed with distilled water and immediately frozen at $-20^{\circ} \mathrm{C}$, and one was preserved in $70 \%$ ethanol. The latter sample was used for sorting and taxonomic identification, carried out with a Leica M3Z stereo microscope (x65 to x160 magnification) to genus and species whenever possible. The relative abundance (in \%) of each identified taxa to the total abundance in number (individuals. $\mathrm{m}^{3}$ ) and in biomass (mg. $\mathrm{m}^{3}$ ) was determined. For the relative abundance in number, the number of organisms belonging to each identified taxa was reported to the total number of organisms. For the relative abundance in biomass, the biomass of each identified taxa in the sample was first estimated from the formula reported by Richardson et al. (2006) for zooplankton, and derived from the allometric relationships by Peters (1983):

Biomass identified taxa $\left(\mathrm{mg} . \mathrm{m}^{3}\right)=\left(0.08^{*}\left(\mathrm{~L}_{\text {identified taxa }}(\mathrm{mm})\right)^{2.1}\right)^{*}$ abundance in number identified taxa (individuals. $\mathrm{m}^{3}$ )

with $L$ identified taxa corresponding to the average size (total body length, $L$ ) of the identified taxa. Such species sizes were mainly taken from Rose (1933) and Richardson et al. (2006), especially for copepod species.

This biomass calculated for each identified taxa was finally reported to the total biomass (with total biomass $=\sum$ (Biomass identified taxa) $)$ to get the relative abundance (in \%) of identified taxa in biomass (Table 1).

For each station, within the $70 \%$ ethanol sample of mesozooplankton, identified taxa contributing at least to $5 \%$ of the total abundance of the sample both in number and in biomass (i.e., -dominant species"), and likely to be part of sardines' and anchovies' diet (i.e., species that may be found in stomach contents of anchovies from the Bay of Biscay area as reported by Plounevez and Champalbert, 1999) were sorted. These dominant species" were finally analysed for their stable isotope ratios (see Tables 1 and 2). Indeed, it has been proven that the diet and the food consumption of sardines and anchovies are strongly dependent on prey density and/or availability (e.g., Costalago et al., 2012; Nikolioudakis et al., 2012b). However, to avoid an underestimation of small species in the diet of planktivorous fish, some species particularly abundant in number and thus contributing to more than $10 \%$ to the total abundance in number (but not in biomass because of their small size) have been analysed and included in the models as well. This was the case of copepod nauplii in station C1, and of Oithona sp. in stations SI1 and SI3 (Table 1).

In order to compare isotope values $\left(\delta^{13} \mathrm{C}\right.$ and $\left.\delta^{15} \mathrm{~N}\right)$ between northern and southern areas or between coastal and oceanic stations, the copepod species Calanus helgolandicus and Acartia sp. were considered. Indeed, these species were sampled in the various areas of concern in the Bay of Biscay (Table 2) to evaluate spatial differences.

20 to 350 individuals (depending on the species' size) belonging to each dominant species were taken out of the ethanol and carefully washed with distilled water in order to completely remove the ethanol and/or dead organic matter and phytoplankton. On average, 200 to 350 individuals per station were sorted for small species (e.g., individuals of Oithona sp.) with a size generally lower than $1.0 \mathrm{~mm}$; between 50 and 200 organisms were sorted for species with individuals between 1.0 and $2.0 \mathrm{~mm}$ (e.g., Temora sp.); finally, less than 50 organisms were sorted for analysing species with individuals larger than $2.0 \mathrm{~mm}$ (e.g., large C. helgolandicus). 
Sorted and washed organisms were finally stored frozen $\left(-80^{\circ} \mathrm{C}, 48 \mathrm{~h}\right)$ before being freezedried (24h). A pool of individuals for each species sorted by station was then packed into two tin-capsules for stable isotope analysis (i.e., half of the sorted organisms within each capsule) in order to assess any kind of variation in the $\delta^{13} \mathrm{C}$ and $\delta^{15} \mathrm{~N}$ values of samples. Two tin-capsules were also made for mesozooplanktonic assemblages (previously ground manually and reduced to a fine powder). Plankton samples were not acidified to remove carbonates because too little matter was available and because a similar study did not find any significant changes in the relative abundance of ${ }^{13} \mathrm{C}$ and ${ }^{15} \mathrm{~N}$ before and after acidification (Bode et al., 2004).

Adult sardines and anchovies were collected during the daylight period around transects using pelagic trawls when shoals were detected with on-board acoustic instruments. Individuals were collected in eight trawls for sardine and seven trawls for anchovy over the continental shelf (Fig. 1). In some trawls both species occurred - however this does not indicate that they come from the same shoal given the duration of each trawl (between half an hour and one hour). Fish were immediately stored frozen at $-20^{\circ} \mathrm{C}$ until further dissection and analyses. 40 sardines and 34 anchovies of similar size classes (average total length of $17.3 \pm 2.6 \mathrm{~cm}$ and $14.6 \pm 1.8 \mathrm{~cm}$ for sardines and anchovies, respectively) were finally defrosted and dissected at the laboratory to obtain portions of dorsal white muscle (Pinnegar and Polunin, 1999). Samples were then washed with distilled water and individually stored frozen at $-20^{\circ} \mathrm{C}$ in plastic bags prior to a $72 \mathrm{~h}$ freeze-drying period. White muscles were ground manually or with a planetary ball mill (Retsch PM 200). They were treated with cyclohexane as described by Chouvelon et al. (2011) in order to remove naturally ${ }^{13} \mathrm{C}$ depleted lipids (De Niro and Epstein, 1977). Cyclohexane is a non-chlorinated solvent with low toxicity that allows for a rapid extraction of total lipids in tissues of marine organisms (Smedes, 1999). It also presents the advantage of not impacting upon isotope values (notably $\delta^{15} \mathrm{~N}$ values), as can the more commonly used chloroform-methanol or dichloromethane-methanol mixtures (e.g., Post et al., 2007; Schlechtriem et al., 2003). Delipidated (i.e., lipid-free) samples were finally dried in an oven at $45^{\circ} \mathrm{C}$ for $48 \mathrm{~h}$ and then packed in tin-capsules.

\subsection{Assessment of preservation and delipidation effects on mesozooplankton isotope values}

As different methods of preservation were used for predators (fish frozen at $-20^{\circ} \mathrm{C}$ ) and for prey (plankton preserved on board in $70 \%$ ethanol for practical reasons, i.e., minimal time and difficulty of direct sorting on board and freezing), supplemental mesozooplanktonic material was collected in 2012 during a cruise (PELGAS 2012) to assess the potential effect of preservation on the $\delta^{13} \mathrm{C}$ and $\delta^{15} \mathrm{~N}$ values of whole mesozooplankton assemblages. For each of the 12 stations randomly selected in the Bay of Biscay area for this purpose (i.e., in the northern and southern part, from coastal to oceanic waters and over the continental shelf), two mesozooplankton samples were collected and preserved following the same protocol than in 2010. Back at the laboratory, the ethanol sample was treated in the same way as sorted mesozooplanktonic organisms in 2010, and after freeze-drying both samples (frozen and ethanol-preserved samples) were finally ground into a fine powder until further isotopic analyses. Time of storage of these samples was of 3 months.

As predators (fish) were delipidated with cyclohexane but prey were not (plankton were analysed directly for practical reasons, i.e., the avoidance of a loss of matter because of small quantities), the supplemental mesozooplanktonic material collected in 2012 was also used to assess for a potential effect of delipidation (with cyclohexane) on the $\delta^{13} \mathrm{C}$ and $\delta^{15} \mathrm{~N}$ values of whole mesozooplankton assemblages. Indeed, some planktonic species (e.g., C. helgolandicus) may present considerable amounts of lipids in their tissues and empirical corrections for lipids are thus proposed in the literature for aquatic zooplankton (e.g., Smyntek et al. 2007). However, these corrections are based on lipid extraction using other 
solvents than cyclohexane (e.g., chloroform-methanol mixtures). For greater consistency with the organisms studied in the area and the method used for lipid extraction in predators (i.e., cyclohexane), we thus used the parameters of regression that had been obtained for further correction of $\delta^{13} \mathrm{C}$ and $\delta^{15} \mathrm{~N}$ values of our planktonic samples (see section 3.1). However, we also previously investigated the potential of $\mathrm{C} / \mathrm{N}$ ratios of untreated samples as a potentially good predictor of observed changes in isotope values when lipids are removed. To this end, the relationships between $\mathrm{C} / \mathrm{N}$ ratios of untreated sample (proxy of lipid content) and mean difference in $\delta^{13} \mathrm{C}$ and $\delta^{15} \mathrm{~N}$ values (absolute value) between delipidated and untreated samples were analysed for mesozooplanktonic assemblages and the copepod species C. helgolandicus sampled in 2010.

\subsection{Stable isotope analysis}

The natural abundance of carbon and nitrogen stable isotopes in plankton and fish was determined with a Thermo Scientific Delta V Advantage mass spectrometer coupled to a Thermo Scientific Flash EA1112 elemental analyser. Results are expressed as isotope ratios $\delta X(\%)$ relative to international standards (Pee Dee Belemnite for carbon and atmospheric $\mathrm{N}_{2}$ for nitrogen), according to the formula:

$\delta X=\left[\left(R_{\text {sample }} / R_{\text {standard }}\right)-1\right] * 10^{3}$

where $X={ }^{13} \mathrm{C}$ or ${ }^{15} \mathrm{~N}$ and $\mathrm{R}={ }^{13} \mathrm{C} /{ }^{12} \mathrm{C}$ or ${ }^{15} \mathrm{~N} /{ }^{14} \mathrm{~N}$ (Peterson and Fry, 1987). Replicate measurements of internal laboratory standards (acetanilide) indicated a precision of approximately $0.2 \%$ for both $\delta^{13} \mathrm{C}$ and $\delta^{15} \mathrm{~N}$ values.

\subsection{Statistical analyses}

All analyses were conducted with the $R$ software (R Development Team, 2011). Normality of mesozooplankton or fish $\delta^{13} \mathrm{C}$ and $\delta^{15} \mathrm{~N}$ values was tested using Shapiro-Wilk's test prior to statistical analyses, i.e., for further use of parametric or non-parametric statistics when comparing two series of samples.

First, the difference in $\delta^{13} \mathrm{C}$ and $\delta^{15} \mathrm{~N}$ values between the two tin-capsules made for sorted mesozooplanktonic organisms (i.e., entities "species-station ») or for mesozoplanktonic assemblages was tested by a Student t-test for paired samples. The relationships between both replicates were close-to-one relationships both for identified organisms and for assemblages (Fig. 2). The difference was not significant in both cases ( $p=0.567$ and $p=$ 0.086 for $\delta^{13} \mathrm{C}$ and $\delta^{15} \mathrm{~N}$ values, respectively) and was below the analytical error (i.e., $0.2 \%$ ) of the Elemental Analyser-Isotopic Ratio Mass Spectrometer (absolute mean of the difference $=0.01 \%$ for $\delta^{13} \mathrm{C}, 0.08 \%$ for $\delta^{15} \mathrm{~N}$ ). Therefore, for each sample (i.e., entity « species-station »), the mean value of the two capsules has been used in further data analyses.

To assess for the effects of preservation and delipidation, a Pearson correlation coefficient was used to compare $\delta^{13} \mathrm{C}$ and $\delta^{15} \mathrm{~N}$ values between frozen and $70 \%$ ethanol mesozooplanktonic bulk samples, and between frozen preserved bulk samples and frozen preserved delipidated samples. A linear regression was applied for the relationship between samples, and Student t-tests for paired samples were used to assess for the effects of preservation and delipidation. Finally, depending on conditions satisfied for parametric statistics or not, Student's or Wilcoxon's tests were used to compare mean $\delta^{13} \mathrm{C}$ and $\delta^{15} \mathrm{~N}$ values between northern and southern fish (i.e., transects T1 and T2 for plankton are considered to be in the northern area, while transects T3 to T5 are considered to be in the southern area, the Gironde's river plume being judged as a potential physical barrier to plankton's spreading; Fig. 1). 
To account for the many potential prey items in the diets of sardine and anchovy, for the wide variability in the $\delta^{13} \mathrm{C}$ and $\delta^{15} \mathrm{~N}$ values of sources, and for the uncertainty in Trophic Enrichment Factors (TEFs) (i.e., difference $(\Delta)$ of $\delta^{13} \mathrm{C}$ or $\delta^{15} \mathrm{~N}$ between the predator's tissue analysed and its diet), Bayesian isotopic mixing models were used (available as an open source R package SIAR - Stable Isotope Analyses in R; Parnell et al., 2010). This program uses Markov Chain Monte Carlo (MCMC) and Dirichlet prior distribution to fit a Bayesian model of a species' dietary habits, based on $\delta^{13} \mathrm{C}$ and $\delta^{15} \mathrm{~N}$ values of individuals of the species. By default, MCMC was run for 500,000 iterations, discarding the first 50,000 to avoid poor starting values and keeping every 15 iterations to reduce the sample autocorrelation.

One to four « dominant species " were analysed for stable isotope ratios for each of the 13 stations sampled (Table 1). As it is not possible to include too many sources in a mixing model (Philips et al., 2005), the 34 entities « species-station » (i.e., potential prey) finally analysed for isotopes were thus grouped prior to running SIAR. This grouping was performed through a Hierarchical Cluster Analysis (HCA), based on $\delta^{13} \mathrm{C}$ and $\delta^{15} \mathrm{~N}$ values, average size of organisms, and geographical coordinates of each entity "species-station " analysed for isotopes ratios. The groups defined by HCA were finally used for mixing modelling (Table 3 ).

Finally, to the best of our knowledge, precise TEFs are unknown for either planktonfeeding fish species studied here (i.e., sardines and anchovies). There is also increasing evidence in the literature that TEFs may be highly variable as a function of the consumer's taxa or as a function of the type and the quality of the consumer's food (e.g., Caut et al., 2009; Vanderklift and Ponsard, 2003), and even Bayesian models outputs may be very sensitive to the chosen TEFs (e.g., Bond and Diamond, 2011). Therefore, to apply sensitivity analyses on the results obtained in the present study, four mixing models by species were run using four very different values of TEFs found in the literature for both $\delta^{13} \mathrm{C}$ and $\delta^{15} \mathrm{~N}$ (Post, 2002, for general values in food webs; Pinnegar and Polunin, 1999; Sweeting et al. 2007ab and Trueman et al., 2005 for fish muscle in particular; see Table 4 for the detailed TEFs used). The variability around $\delta^{13} \mathrm{C}$ and $\delta^{15} \mathrm{~N}$ values of each source taken into account in the mixing models corresponded to the standard deviation around the mean of each source group (i.e., SD given in Table 3).

\section{Results}

\subsection{Effects of preservation and delipidation in assemblages of mesozooplankton}

The relationships between $\mathrm{C} / \mathrm{N}$ ratios of untreated sample and mean difference in $\delta^{13} \mathrm{C}$ and $\delta^{15} \mathrm{~N}$ values (absolute value) between delipidated and untreated samples did not show any pattern in the case of mesozooplanktonic assemblages, nor for $C$. helgolandicus samples (Fig. 3).

A significant effect of the preservation method (storage in $70 \%$ ethanol vs. freezing at $-20^{\circ} \mathrm{C}$ ) was found for both $\delta^{13} \mathrm{C}$ and $\delta^{15} \mathrm{~N}$ values in mesozooplankton (Student t-tests for paired samples, $p<0.001$ in both cases). Also, the Pearson correlation coefficient between frozen and $70 \%$ ethanol mesozooplanktonic bulk samples was highly significant for both elements $\left(R^{2}=0.951\right.$ and $R^{2}=0.952$ for $\delta^{13} C$ and $\delta^{15} N$, respectively, both $\left.p<0.001\right)$. There was a clear trend towards higher $\delta^{13} \mathrm{C}$ and $\delta^{15} \mathrm{~N}$ values when mesozooplanktonic samples were preserved in $70 \%$ ethanol relative to frozen preserved material (Fig. 4). The mean difference between values of ethanol-preserved samples and those of frozen-preserved samples was of $0.9 \%$ for $\delta^{13} \mathrm{C}$ and $0.7 \%$ for $\delta^{15} \mathrm{~N}$. The $\delta^{13} \mathrm{C}$ and $\delta^{15} \mathrm{~N}$ values of all mesozooplanktonic organisms preserved in $70 \%$ ethanol were thus corrected to take into account this effect of preservation. The correction applied followed the parameters of the equation for the 
corresponding relationships (i.e., the relationship between frozen and $70 \%$ ethanol mesozooplanktonic bulk samples; Fig. 4):

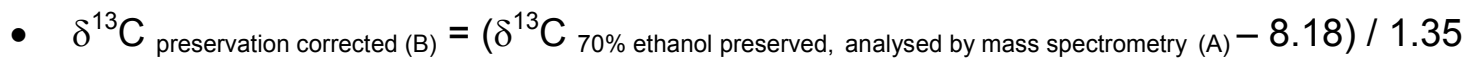

- $\delta^{15} \mathrm{~N}_{\text {preservation corrected (B) }}=\left(\delta^{15} \mathrm{~N} 70 \%\right.$ ethanol preserved, analysed by mass spectrometry (A) -1.23$) / 0.92$

A significant effect of the delipidation by cyclohexane was also found for both $\delta^{13} \mathrm{C}$ and $\delta^{15} \mathrm{~N}$ values in mesozooplankton (Student t-tests for paired samples, $p<0.001$ and $p=0.005$ for $\delta^{13} \mathrm{C}$ and $\delta^{15} \mathrm{~N}$, respectively). The Pearson correlation coefficient between frozen preserved bulk samples and frozen preserved delipidated samples was very high and significant for both elements $\left(R^{2}=0.889\right.$ and $R^{2}=0.994$ for $\delta^{13} C$ and $\delta{ }^{15} N$, respectively, both $\left.p<0.001\right)$. There was a trend towards higher $\delta^{13} \mathrm{C}$ values when mesozooplanktonic samples were delipidated relative to bulk material (Fig. 4), and the mean difference was of $0.7 \%$. Although significant, the mean difference was only of $0.1 \%$ for $\delta^{15} \mathrm{~N}$ (i.e., lower than the analytical error of the analyser of about $0.2 \%$ ) and there was no clear trend, as values were very close to the correspondence 1:1 line (Fig. 4). Thus, only $\delta^{13} \mathrm{C}$ values were then corrected for the lipid effect, following the parameters of the equation for the corresponding relationships (i.e., relationship between frozen preserved bulk samples and frozen preserved delipidated samples; Fig. 4), also taking into account the preservation effect:

- $\delta^{13} \mathrm{C}_{\text {preservation and delipidation corrected (C) }}=\left(0.76{ }^{*} \delta^{13} \mathrm{C}_{\text {preservation corrected (B) }}\right)-4.16$

$\delta^{13} \mathrm{C}$ and $\delta^{15} \mathrm{~N}$ values of all sorted mesozooplanktonic organisms analysed and further used in statistical analyses were thus: $\delta^{13} \mathrm{C}$ preservation and delipidation corrected (C) values and $\delta^{15} \mathrm{~N}$ preservation corrected (B) values. $\delta^{13} \mathrm{C}$ values of undetermined assemblages analysed for comparison with values of sorted organisms within a station were only corrected for the lipid effect, as they were stored frozen. Corrected values were also used in the mixing models to keep the preservation method and the treatment for lipid effect consistent between prey and predators.

\subsection{Mesozooplanktonic assemblages: taxonomic identification and $\delta^{13} \mathrm{C}$ and $\delta^{15} \mathrm{~N}$ values of undetermined assemblages relative to sorted organisms}

Taxonomic assemblages observed during this study highlighted that in the Bay of Biscay - at least in spring 2010 - oceanic stations are characterised by the large copepod species C. helgolandicus, while the smaller copepod Temora sp. characterises coastal stations (Table 1). Shelf stations usually displayed a mixing of coastal and oceanic species. Most of the identified dominant species were quite common and could be found in the north as well as in the south of the Bay of Biscay (Table 1). Finally, some genus or species like Acartia sp. were found in coastal but also in oceanic zones, notably in the south of the Bay of Biscay.

To compare $\delta^{13} \mathrm{C}$ and $\delta^{15} \mathrm{~N}$ values of undetermined assemblages relative to those of sorted organisms within a station (Fig. 5), only stations where copepods represented $\geq 90 \%$ of the total abundance both in number and biomass, and wherein at least three dominant species of copepods representing $\geq 90 \%$ of the copepod abundance in biomass were analysed for isotope ratios, were selected (i.e., in Table 1: stations SI1, SI3 and SI4). As such, undetermined assemblages generally presented intermediate isotope values between the lowest and the highest $\delta^{13} \mathrm{C}$ and $\delta^{15} \mathrm{~N}$ values of the sorted copepods within a station. $\delta^{13} \mathrm{C}$ and $\delta^{15} \mathrm{~N}$ values of undetermined assemblages did not reflect the high diversity of isotope values of the dominant species analysed within a station (Fig. 5). 


\subsection{Intra-station variability of mesozooplankton $\delta^{13} \mathrm{C}$ and $\delta^{15} \mathrm{~N}$ values}

Within each station, isotope ratios of dominant species were distinct, regardless of the location (north or south, coast or slope). Fig. 4 illustrates this phenomenon for five stations taken as examples for clarity reasons, although similar patterns could be observed for other stations of this study. Thus, for the offshore station SI1, there was a $2.9 \%$ difference between the lowest $\delta^{15} \mathrm{~N}$ value (Oithona sp. with 3.5\%) and the highest (C. helgolandicus with 6.4\%o). Intermediate values were displayed by the undetermined species of Calanoid $(4.4 \% 0)$. A same pattern could be noticed for the offshore station $\mathrm{SI} 3$ with a 3.4\%o difference between the lowest $\delta^{15} \mathrm{~N}$ value (Oithona sp. with 3.2\%o) and the highest (C. helgolandicus with 6.6\%), the undetermined species of Calanoid presenting an intermediate $\delta^{15} \mathrm{~N}$ value $(4.6 \%)$.

$\delta^{13} \mathrm{C}$ values were generally less variable (Fig. 4). The highest magnitude was found within station Sh5 (not shown), with values comprised between -19.2\%o (Temora sp.) and -20.9\%o (undetermined Calanoid).

\subsection{Intra-specific spatial variability of mesozooplankton $\delta^{13} \mathrm{C}$ and $\delta^{15} \mathrm{~N}$ values}

The variability in isotope values within the two species revealed differences between the northern and southern areas on the one hand (with $C$. helgolandicus sampled in offshore stations), and differences between the coast and slope on the other hand (with Acartia sp. sampled both near the coast and near the slope in the southern area) (Fig. 6). $\delta^{15} \mathrm{~N}$ values of $C$. helgolandicus displayed a relatively low variation between north and south, with the smallest value belonging to station SI1 (north, 6.4\%) and the highest value for station SI4 (south, 7.3\%o). However, $\delta^{13} \mathrm{C}$ values showed a higher variation from the north to the south for this species. The smallest value appeared for station SI3 (south, $-22.2 \%$ ) and the highest for SI2 (north, $-19.7 \%$ ), corresponding to a $2.5 \%$ variation.

$\delta^{13} \mathrm{C}$ values of Acartia sp. did not vary much from the coast to the slope along transect 4 ($20.3 \%$ for C4, against $-20.9 \%$ for SI4), even if a slightly lower value could be noticed for the offshore station (SI4). As for $\delta^{15} \mathrm{~N}$ values, the range of variation was more important, varying from $6.0 \%$ for SI4 (slope) to $8.6 \%$ for C4 (coast) (Fig. 6).

\subsection{Mesozooplanktonic prey groups}

The HCA performed on $\delta^{13} \mathrm{C}$ and $\delta^{15} \mathrm{~N}$ values, average size of organisms and geographical coordinates of each entity "species-station " analysed for isotopes ratios defined eight groups of mesozooplanktonic prey (Fig. 7) which were then used in isotopic models. These groups were in accordance with the general patterns of variability of isotopes values previously found for mesozooplankton, thus respecting a certain ecological significance for further interpretations of the results of isotopic models (Tables 3 and 4).

\subsection{Variability of sardine and anchovy $\delta^{13} \mathrm{C}$ and $\delta^{15} \mathrm{~N}$ values}

$\delta^{15} \mathrm{~N}$ values of anchovies caught in the north were not significantly different to those of anchovies caught in the south (Fig. 8; Student t-test, $p=0.19$ ). The same statement could be made for $\delta^{13} \mathrm{C}$ values (Wilcoxon test, $\mathrm{p}=0.23$ ). Also, no significant difference was observed for the $\delta^{13} \mathrm{C}$ and $\delta^{15} \mathrm{~N}$ values between northern and southern sardines (Student t-tests, $p=0.09$ and $p=0.37$, respectively). As a consequence, no distinction was then made between northern and southern individuals for both species. The average $\delta^{13} \mathrm{C}$ and $\delta^{15} \mathrm{~N}$ values were respectively of $-18.4 \pm 0.4 \%$ and $9.8 \pm 0.6 \%$ for anchovy and $-17.8 \pm 0.3 \%$ and $10.9 \pm 0.5 \%$ for sardine (Table 2 ). These values were significantly different between the two species (Student t-test and Wilcoxon test for $\delta^{13} \mathrm{C}$ and $\delta^{15} \mathrm{~N}$ values respectively, both $\mathrm{p}<0.001)$. 


\subsection{Prey-predator relationships}

An average value for the estimated contribution of each group of mesozooplanktonic prey was calculated, from the four mixing models applied with the different TEFs (Table 4). For S. pilchardus, it appeared that this predator preferentially consumes two to three mesozooplankton groups (i.e., groups whose estimated contribution in the diet is $\geq 10 \%$ on average), whatever the TEFs used. The first two groups (groups 4 and 8) corresponded to small- to medium-sized organisms (e.g., copepods Acartia sp., Temora sp.) from neritic waters of the Bay of Biscay, i.e., from the coast to the shelf in the northern part (group 4) as well as from the coast to the shelf in the central to southern part (group 8), with an average contribution given by the four models of $28.9 \pm 9.6 \%$ and $43.7 \pm 5.9 \%$, respectively (Table 4 ). The third group with an average contribution $\geq 10 \%$ (group 5: $14.7 \pm 9.5 \%$ ) corresponded to large organisms (i.e., the copepod $C$. helgolandicus) from the shelf to the slope in the northern part of the Bay of Biscay, but its contribution to the diet of sardines was highly dependent of the TEF used (Table 4).

In the case of anchovies, several mesozooplanktonic groups (five out of the eight defined) were identified as main contributors by mixing models (i.e., contribution $\geq 10 \%$ on average). The same three groups as for sardines slightly stand out from the others: the groups 4,5 and 8 with average estimated contributions in the diet of anchovy of $19.3 \pm 7.7 \%, 17.6 \pm 10.0 \%$ and $22.3 \pm 7.7 \%$, respectively. There was a quite high variability of contribution values for the different groups in anchovies, depending on the TEFs used (Table 4).

\section{Discussion}

In the French part of the Bay of Biscay, published data on the diet of sardine and anchovy and small pelagic planktivorous species in general - are very scarce, especially stomach contents data (e.g., Plounevez and Champalbert, 1999). More generally in European waters, these studies are scarce and generally focused on one species at a time (e.g., Bacha and Amara, 2009; Borme et al., 2009; Cunha et al., 2005; Garrido et al., 2007, 2008; Nikolioudakis et al., 2012ab; Raab et al., 2011; Sever et al., 2005). For the first time, this study investigated the trophic ecology of both species simultaneously through stable isotopes analysis in the Bay of Biscay area, also exploring the variability of isotope values that may occur in the mesozooplanktonic prey (inter-specific and spatial variations in particular) to better interpret isotope values of fish, and to run more effective mixing models.

\subsection{Analysing stable isotopes in mesozooplankton}

First, this study showed how preservation and lipid-correction methods (i.e., delipidation) might have an impact when conducting SIA in mesozooplankton for studying pelagic trophic relationships. Very few studies have effectively investigated the effect of preservation on planktonic organisms before (e.g., Feuchtmayr and Grey, 2003), and studies available on this topic generally focus on specific tissues of larger organisms (e.g., Kaehler and Pakhomov, 2001; Sarakinos et al., 2002; Sweeting et al., 2004). Results obtained here for mesozooplanktonic assemblages highlight a clear and predictable trend to increased $\delta^{13} \mathrm{C}$ and $\delta^{15} \mathrm{~N}$ values of mesozooplankton when preserved in $70 \%$ ethanol relative to frozen samples. We thus propose that the relationships used here (Fig. 3) may be used to correct $\delta^{13} \mathrm{C}$ and $\delta^{15} \mathrm{~N}$ values of marine temperate mesozooplankton from the effect of a $70 \%$ ethanol preservation. This is valuable even when the time of preservation is relatively short (i.e., some months, as undergone for the samples tested in this study). Due to technical reasons in the field, the identification, sorting and freezing of mesozooplankton directly after sampling (i.e., on board) is effectively very difficult, and a chemical preservation generally has to be 
made to further work on samples back in the laboratory (and finally, to carry out isotopic analyses).

The delipidation of samples is generally recommended in the literature to avoid an effect of lipids on $\delta^{13} \mathrm{C}$ values (Post et al., 2007). Lipids are effectively considerably depleted in ${ }^{13} \mathrm{C}$ relative to other tissue components (e.g., De Niro and Epstein, 1977). Differences of lipid burden may thus constrain the comparison of isotopic data between individuals and/or species with very different fat contents. Also, the delipidation of samples has to be applied to all organisms used in analyses (including predators, prey and baseline organisms) for estimating diet source for example (Post et al., 2007). This is often done with chloroformmethanol or dichloromethane-methanol mixtures. However, these methods are still discussed in the literature as they can impact $\delta^{15} \mathrm{~N}$ values (e.g., Murry et al., 2006; Post et al., 2007; Sotiropoulos et al., 2004), because these solvents are not specific for lipids and may also extract nitrogen compounds (Radin, 1981). We thus used cyclohexane to delipidate fish muscle samples, as it is a non-chlorinated solvent with low toxicity that allows for a rapid extraction of total lipids in tissues of marine organisms (Smedes, 1999). Also, internal laboratory experiments still in progress suggest that cyclohexane significantly affects $\delta^{13} \mathrm{C}$ values of fat muscle samples only (i.e., samples with bulk $\mathrm{C} / \mathrm{N}>3.5$; Post et al., 2007) without affecting $\delta^{15} \mathrm{~N}$ values (Chouvelon et al., unpublished data). However, due to practical reasons (i.e., the possible loss of matter and low quantities of matter), delipidation was not possible on sorted mesozooplanktonic organisms analysed in this study. For the first time to the best of our knowledge, the results obtained here for mesozooplanktonic assemblages highlight a clear and predictable trend to increased $\delta^{13} \mathrm{C}$ values of mesozooplankton when delipidated with cyclohexane, relative to bulk samples (Fig. 4). This confirms the necessity to correct $\delta^{13} \mathrm{C}$ values for lipids in marine temperate mesozooplanktonic organisms also, as previously suggested in aquatic mesozooplankton in general by Smyntek et al. (2007). The results also highlighted that cyclohexane is efficient to correct for lipids on $\delta^{13} \mathrm{C}$ values without affecting $\delta^{15} \mathrm{~N}$ values of whole mesozooplanktonic samples (see above), so this method can be used to delipidate mesozooplanktonic assemblages. However, when delipidation is not possible (i.e., on sorted organisms due to low quantity of matter, see above), we propose that the relationships used here (Fig. 4) may be used to correct $\delta^{13} \mathrm{C}$ values of marine temperate mesozooplankton species for lipids. Indeed, all mesozooplanktonic species of this study (that could not be delipidated) presented bulk $\mathrm{C} / \mathrm{N}$ ratios $\geq 3.5$ (i.e., high fat contents samples; Post et al., 2007), and all individuals of the copepod $C$. helgolandicus analysed even presented $\mathrm{C} / \mathrm{N}$ ratios $\geq 6.0$, for instance. Besides, we showed that the $\mathrm{C} / \mathrm{N}$ ratio is not always a good predictor of observed changes in isotope values when lipids are removed (Fig. 3), as the relationship between bulk $\mathrm{C} / \mathrm{N}$ and $\Delta \delta^{13} \mathrm{C}$ $\left(=\delta^{13} \mathrm{C}\right.$ delipidated sample $-\delta^{13} \mathrm{C}$ bulk/untreated sample) normally used for mathematical correction (e.g., Smyntek et al., 2007) was not linear (Fig. 3); there was thus the need to correct all values for lipids for further treatment of the planktonic isotopic data in this study.

Then, this study showed how critical it is to work on identified mesozooplanktonic species or genus rather than on undetermined mesozooplanktonic assemblages when conducting advanced investigations on low trophic levels of the pelagic food webs using stable isotopes (Fig. 5). Indeed, isotopic signatures $\left(\delta^{13} \mathrm{C}\right.$ and $\delta^{15} \mathrm{~N}$ values) of target planktonic species may not be well represented when determination of isotope ratios are made on whole (undetermined) mesozooplankton assemblages, as it is possible to find within the later a high quantity of phytoplankton (e.g., Ceratium sp.) or detritical organic matter, especially in coastal areas. Moreover, autotrophic organisms can agglomerate and fill in planktonic nets, hence keeping smaller organisms than required (e.g., nauplii, cladocerans) (e.g., Lefèvre, 1946). It is then difficult to assess to what extent $\delta^{13} \mathrm{C}$ and $\delta^{15} \mathrm{~N}$ values of an undetermined assemblage may reflect those of the dominant species within this assemblage, even when these species represent almost the total abundance in biomass of the whole mesozooplankton assemblage (i.e., $\geq 90 \%$ in the case of the three stations presented in Fig. 
5). What is certain is that whole assemblages do not reflect the variability of $\delta^{13} \mathrm{C}$ and $\delta^{15} \mathrm{~N}$ values existing among the different dominant species, and for the main purpose of this study (i.e., unravelling sardines' and anchovies' diets through SIA) there was above all considerable interest in the intra-station and inter-species variability of mesozooplankton $\delta^{13} \mathrm{C}$ and $\delta^{15} \mathrm{~N}$ values. The results effectively highlight that $\delta^{13} \mathrm{C}$ and $\delta^{15} \mathrm{~N}$ values of distinct mesozooplanktonic species can be really different for a given station (Fig. 5). For instance, a $3.4 \%$ difference in $\delta^{15} \mathrm{~N}$ between the smallest organism (Oithona $\mathrm{sp}$.) and the largest (C. helgolandicus) could be noticed in station SI3. This difference corresponds to one trophic level if we consider the widely used trophic enrichment factor of $3.4 \%$ between two trophic levels (e.g., De Niro and Epstein, 1981; Minagawa and Wada, 1984; Post, 2002). However, this value has been set following studies that mainly focused on vertebrate's body parts and/or tissues. Crustaceans seem to have generally lower ${ }^{15} \mathrm{~N}$ fractionation values than vertebrates (around 2\%ovs. 2.5 to more than 3\%) (Vanderklift and Ponsard, 2003). Thus, the $3.4 \%$ difference in $\delta^{15} \mathrm{~N}$ between these two zooplanktonic species (i.e., Oithona sp. and $C$. helgolandicus in station $\mathrm{SI} 3$ ) would in fact correspond to more than one trophic level. These heterogeneous $\delta^{13} \mathrm{C}$ and $\delta^{15} \mathrm{~N}$ values for the different mesozooplanktonic species within the same station point out a great inter-taxonomic variability in zooplankton fractionation or diets. The latter has already been detected many times within planktonic organisms and seems particularly influenced by biological conditions and individual size (e.g., Batten et al., 2001; Hansen et al., 1994; Kleppel et al., 1988; Paffenhöfer and Knowles, 1980). It can also be linked to omnivory, which is usual in copepods' behaviour (e.g., Conley and Turner, 1985; Dam and Lopes, 2003).

\subsection{Spatial variability of mesozooplankton signatures}

When working on such a great spatial scale as the Bay of Biscay, the geographic area where the organisms are sampled must also be carefully considered. Indeed, species caught in coastal zones generally displayed higher $\delta^{13} \mathrm{C}$ and $\delta^{15} \mathrm{~N}$ values than those caught in offshore areas. This is illustrated by Acartia sp. found in two stations of the same transect (Fig. 6). Despite the short length (around $64 \mathrm{~km}$ ) between the coastal station (C4) and the offshore one (SI4), a $2.6 \%$ range could be observed for $\delta^{15} \mathrm{~N}$. Such a gap can be attributed to a different diet of Acartia sp. between areas or to nitrogen inputs from the land influencing the signature of coastal organisms. In fact, oceanic food webs generally present lower $\delta^{13} \mathrm{C}$ and $\delta^{15} \mathrm{~N}$ values than neritic food webs (Fry, 1988; Kelly, 2000). According to Fry (1988), coastal zones may effectively face strong nitrogen inputs from the continent that are enriched in ${ }^{15} \mathrm{~N}$. This author also stated that the $\delta^{15} \mathrm{~N}$ of a consumer results from a mixture of sources, isotopically" distinct, that would bias the trophic level estimations if no distinction between the habitats are made. As $\delta^{15} \mathrm{~N}$ seems to be higher in coastal copepods than in oceanic ones, nitrogen could thus, as well as carbon, be used as a chemical marker for tracing the origin of organic matter (e.g., Chouvelon et al., 2012). However, one should remain careful when considering offshore systems because the denitrification process could modify the isotope composition of available nitrate to phytoplankton (for a review on processes affecting $\delta^{15} \mathrm{~N}$ values from the dissolved inorganic nitrogen level, see Montoya, 2007). It is then necessary to take into account this $\delta^{15} \mathrm{~N}$ inshore-offshore pattern for food web studies (Chouvelon et al., 2012).

Latitudinal variations in copepod isotope values also seem to exist, notably for ${ }^{13} \mathrm{C}$ (e.g., Shell et al., 1998). Indeed, a $2.5 \%$ o difference in $\delta^{13} \mathrm{C}$ can be noticed for $C$. helgolandicus between northern and southern stations (Fig. 6). This result confirms the use of carbon as a tracer of the food web's primary producers as previously reported (Hobson and Welch, 1992; Peterson, 1999). Accordingly, this suggests that another distinction must be made when grouping organisms by distinguishing spatial areas, even at a meso-scale (here the northern and southern areas for the Bay of Biscay). Finally, as principal energy fluxes in the pelagic food webs generally occur from the smallest to the biggest organisms (Fenchel, 1988; 
Hansen et al., 1994), and because of the high spatial variability of signatures enhanced by this study in the Bay of Biscay, it was important to keep both spatial and size discriminations for the grouping of mesozooplanktonic organisms to run SIAR (i.e., coast to slope, north vs. south, and small to large organisms), and for further interpretation of the models' results.

\subsection{Isotope values of small pelagic fish}

No spatial pattern was found for European sardine (S. pilchardus) or for European anchovy ( $E$. encrasicolus) analysed in this study. Within the same species, no significant difference in isotopic ratios could be detected between northern and southern fish (Fig. 8). This could be due to a high mobility of $S$. pilchardus and $E$. encrasicolus shown in the Bay of Biscay, which would homogenise their isotope values. This statement contradicts the results obtained by Bode et al. (2004) for sardines of the northwestern shelf of the Iberian Peninsula, where adults seem to experience low mobility between areas. However, in this last area, the continental shelf is only 25 to $30 \mathrm{~km}$ wide on average (Fraga, 1981), whereas it can reach almost $200 \mathrm{~km}$ in the northern part of the Bay of Biscay. On the other hand, our results could be explained by the fact that sampling was realised during the breeding period for both species (May-June). Spawning areas are essentially located in the south of the Bay of Biscay, at least for anchovy that migrates in these areas in spring, and seasonal migrations have also been reported for sardine (ICES, 2010b). Thus, population dispersion could occur during this period and fish captured in a site may not live and feed there the rest of the year.

\subsection{Diet and feeding areas of small pelagic fish}

Overall, the results of the mixing models emphasise the existence of preferential feeding areas within each species. They showed that sardines mostly consume coastal and shelf small- to medium-sized copepods in both northern and southern areas (Table 4). Mixing models also suggest the possibility for sardines to feed on larger species on the shelf or near the slope, in the northern part (i.e., group 5). Sardines are generally thought to be filterfeeding" pelagic fish (e.g., Garrido et al., 2007; Van der Lingen, 1994; Van der Lingen et al., 2009). Thanks to their fine branchial apparatus (Van der Lingen et al., 2006), sardines can effectively filter smaller particles than anchovies (James and Findlay, 1989), like small zooplankton and chain-forming diatoms (Garrido et al., 2007; Van der Lingen et al., 2009). Here, we only analysed a certain size class of adults (i.e., individuals of average total length of $17.3 \pm 2.6 \mathrm{~cm}$ ) and in fact, only larger adult sardines (i.e., $>18 \mathrm{~cm}$ ) would filter-feed" more relative to medium-sized adults we analysed (Bode et al., 2003). Also, most of dietary carbon and/or protein nitrogen are obtained from zooplanktonic prey and not from phytoplankton in adult sardines in general (Bode et al., 2004; Costalago et al., 2012; Nikolioudakis et al., 2012b; Van der Lingen, 1994), and the contribution of phytoplankton to sardines' diet may vary greatly at small spatial scales and seasonally (Garrido et al., 2008). Finally, particulatefeeding" can also occur in sardine, when large prey items are available (Garrido et al., 2007), which could notably explain the contribution of one group with large organisms (group 5). Indeed, in sardine, the diet and the food consumption can be highly dependent on food density and/or availability (e.g., Costalago et al., 2012; Nikolioudakis et al., 2012b).

Similarly to sardine, anchovy seems to mainly feed on small- to medium-sized copepods from the neritic waters in both northern and southern areas, according to the results of mixing models (Table 4). This is consistent with some stomach content analyses available in the literature for anchovy (e.g., Bacha and Amara, 2007; Borme et al., 2009; Plounevez and Champalbert, 1999; Raab et al., 2011). However, two groups (groups 5 and 6) of larger organisms (i.e. the copepod C. helgolandicus) contributed for more than $10 \%$ on average to the diet of anchovy (Table 4), which corroborates, at least in part, the possible feeding of anchovy on the larger-size spectrum of available prey as a particulate-feeder" (Espinoza et 
al., 2009; Van der Lingen, 1994), and the fact that this species is probably not a specialist feeder (Raab et al., 2011).

Thus, there could be some trophic overlap between sardines and anchovies (e.g., Brodeur et al., 2008), as they both seem to mainly feed in the neritic waters of the Bay of Biscay and on the same kind of prey (i.e., mainly small- to medium-sized copepods). Mixing models effectively point out preferential coastal feeding areas (and thus associated planktonic species) for both species of fish, although slightly spreading out near the slope in anchovies (Table 4). Moreover for anchovies, groups of larger prey showed a greater contribution to its diet than for sardines. Sardines and anchovies can feed throughout the year (ICES, 2010b), even during the breeding period. Hatching areas are mainly located in the central to southern parts of the Bay of Biscay for anchovy (i.e., Gironde river's plume), but are not well established for sardine that could use northern as well as southern areas (Bernal et al., 2007; ICES, 2010a). Both species show an exploitation of the neritic waters from the central to southern area for feeding (the prey group 8 presenting an high average contribution in both species). However, during the PELGAS survey in spring 2010 (samples of this study coming from this survey), sardines were largely distributed near the northern coast of the Bay of Biscay, with some schools found near the southern coast and on the southern shelf also (ICES, 2010a). In contrast, anchovies were mainly found on the southern shelf (ICES, 2010a). This suggests, at least for the year 2010, a different exploitation of the Bay of Biscay area by both species for breeding (ICES, 2010a), as well as for feeding according to the isotopic results of this study.

The significant difference between average sardines and anchovies' isotope values (Fig. 8) effectively confirms that these species do not feed on the same prey species or in the same areas. Such significantly lower $\delta^{13} \mathrm{C}$ and $\delta^{15} \mathrm{~N}$ values in anchovy could have been related to the consumption of lower trophic level organisms, or to more offshore feeding habits. However, in several cases, anchovies are found to feed at a slightly higher trophic level than sardines (e.g., Stergiou and Karpouzi, 2002), and specifically in the Bay of Biscay (i.e., data from Ecopath modelling; Lassalle et al., 2011), which invalidates the first hypothesis. Moreover, spatial variability of $\delta^{13} \mathrm{C}$ and $\delta^{15} \mathrm{~N}$ values from the base of the different food webs in the area (Chouvelon et al., 2012), also shown here with isotope values of mesozooplanktonic species, likely supports the second hypothesis.

Finally, mixing models revealed a relative specialisation of sardine on small- to medium-sized organisms from the coast in general, regardless of the TEF used (Table 4). In contrast, anchovy showed a greater trophic plasticity (i.e., no prey group contributing to more than $25 \%$ on average when considering the results of the four models run; Table 4), both in terms of feeding zones and in terms of organisms preyed as the mesozooplanktonic composition vary between areas (Table 1). Furthermore, we tested whether the results of the mixing models changed significantly if the values of mesozooplanktonic prey were not corrected for the lipid effect, but only for the preservation effect. This was not the case, and all of the general patterns of results described above were kept. Hence, with regard to this study's results, one hypothesis is that in order to reduce a negative effect of trophic competition, anchovy from the Bay of Biscay further exploits shelf and offshore regions and also larger prey whereas sardine has a more coastal behaviour. In addition, a temporal segregation could also be set up, with diurnal or nocturnal hunting (e.g., Tudela et al., 2002; Tudela and Palomera, 1997). This resource partitioning between sardines and anchovies has effectively been shown in other marine systems, with sardines being more specialised than anchovies on small zooplanktonic prey (e.g., Espinoza et al., 2009; Van der Lingen et al., 2006). Finally, with the stable isotope technique, the information provided is not of taxonomic precision but more based on the size and on the location of preyed organisms. Only an analysis of stomach contents might give a taxonomic accuracy of the different prey consumed if this represents the purpose of a study. Also, alternatives techniques such as amino-acid specific 
stable nitrogen isotopic compositions could represent a powerful technique for the precise trophic position estimations within the pelagic food web (e.g., Hannides et al., 2009).

\section{Conclusions}

This study first demonstrated that the preservation method of zooplankton can affect both $\delta^{13} \mathrm{C}$ and $\delta^{15} \mathrm{~N}$ values. However, a correction can be applied to further compare isotopic ratios with those of plankton-feeders such as small pelagic fish (if preserved differently). Also, we showed that only one replicate is necessary for the analysis of stable isotope ratios in identified planktonic organisms (several organisms being pooled in the tin-capsule), as well as in mesozooplanktonic assemblages (when previously well homogenised by reducing them to a fine powder). Then, it has been pointed out the interest of working with identified mesozooplanktonic species, as mesozooplanktonic assemblages may contain species with various feeding behaviours (i.e., carnivores, omnivores, etc.) leading to considerable differences in $\delta^{15} \mathrm{~N}$ values of species within the same station. However, as these differences in $\delta^{15} \mathrm{~N}$ values between organisms of a station appeared to be mainly linked to their size (i.e., increasing trophic level with increasing organisms' size within a station), some grouping of organisms in fine size-classes may be possible (i.e., in the Bay of Biscay, small species correspond to the copepods Acartia sp or Oithona sp. for instance, medium species to the copepod Temora sp. for example, and large species almost exclusively to the copepod C. helgolandicus). Nevertheless, if such a grouping of organisms, the importance to well discriminate the areas - notably coastal and offshore - has also been highlighted in this study, as isotope values of mesozooplanktonic organisms can change greatly according to this spatial factor. Ascertaining the spatial variability of isotopic signatures from the base of food chains is effectively of considerable importance, even within the same ecosystem, as this variability may confound estimated trophic positions of predators (here planktivorous fish). In the light of this variability in plankton signatures, the feeding behaviours of $S$. pilchardus and $E$. encrasicolus were finally investigated through mixing models. These models highlighted a privileged feeding area located in neritic waters of the Bay of Biscay for both species, which preferentially looked for small- to medium-sized copepods. However, the trophic plasticity (in terms of foraging areas and thus, associated prey) would be higher in anchovy, suggesting some trophic segregation between fish species. In the future, it would be interesting to investigate potential inter-annual and seasonal variations of the trophic ecology of both species, and to link these potential variations of diet to potential variations in the mesozooplanktonic community.

\section{Acknowledgements}

This work was supported through the $\mathrm{PhD}$ grant of $\mathrm{T}$. Chouvelon from the Conseil Régional de Poitou-Charentes and by the European project REPRODUCE (EratNet-Marifish, FP7). Authors are very grateful to J. Massé, P. Petitgas, and M. Doray from IFREMER for facilitating the sampling during PELGAS surveys. Many thanks to M. Huret and P. Bourriau (IFREMER) for their help during planktonic sample collection, and P. Lespagnol (IFREMER) for fish sampling. Authors also thank P. Richard (UMR LIENSs) for assistance in stable isotope analysis. Finally, they thank anonymous reviewers of earlier versions of the manuscript for their help in improving the manuscript. 


\section{References}

Bacha, M., Amara, R., 2009. Spatial, temporal and ontogenetic variation in diet of anchovy (Engraulis encrasicolus) on the Algerian coast (SW Mediterranean). Estuar. Coast. Shelf S. 85, 257-264.

Batten, S.D., Fileman, E.S., Halvorsen, E., 2001. The contribution of microzooplankton to the diet of mesozooplankton in an upwelling filament off the north west coast of Spain. Progr. Oceanogr. 51, 385-398.

Bernal, M., Stratoudakis, Y., Coombs, S., Angelico, M.M., de Lanzós, A.L., Porteiro, C., Sagarminaga, Y., Santos, M., Uriarte, A., Cunha, E., Valdés, L., Borchers, D., 2007. Sardine spawning off the European Atlantic coast: characterization of and spatio-temporal variability in spawning habitat. Progr. Oceanogr. 74, 210-227.

Blaxter, J.H.S., Hunter, J.R., 1982. The biology of the clupeoid fishes. Adv. Mar. Biol. 20, 1223.

Bode, A., Álvarez-Ossorio, M.T., 2004. Taxonomic versus trophic structure of mesozooplankton: a seasonal study of species succession and stable carbon and nitrogen isotopes in a coastal upwelling ecosystem. ICES J. Mar. Sci. 61, 563-571.

Bode, A., Álvarez-Ossorio, M.T., Carrera, P., Lorenzo, J., 2004. Reconstruction of trophic pathways between plankton and the North Iberian sardine (Sardina pilchardus) using stable isotopes. Sci. Mar. 68, 165-178.

Bode, A., Álvarez-Ossorio, M.T., Cunha, M.E., Garrido, S., Peleteiro, J.B., Porteiro, C., Valdés, L., Varela, M., 2007. Stable nitrogen isotope studies of the pelagic food web on the Atlantic shelf of the Iberian Peninsula. Prog. Oceanogr. 74, 115-131.

Bode, A., Álvarez-Ossorio, M.T., González, N., Lorenzo, J., Rodríguez, C., Varela, M., Varela, M.M., 2005a. Seasonal variability of plankton blooms in the Ria de Ferrol (NW Spain): II. Plankton abundance, composition and biomass. Estuar. Coast. Shelf S. 63, 285300.

Bode, A., Carrera, P., Lens, S., 2003. The pelagic foodweb in the upwelling ecosystem of Galicia (NW Spain) during spring: natural abundance of stable carbon and nitrogen isotopes. ICES J. Mar. Sci. 60, 11-22.

Bode, A., González, N., Rodríguez, C., Varela, M., Varela, M.M., 2005b. Seasonal variability of plankton blooms in the Ria de Ferrol (NW Spain): I. Nutrient concentrations and nitrogen uptake rates. Estuar. Coast. Shelf S. 63, 269-284.

Bond, A.L., Diamond, A.W., 2011. Recent Bayesian stable-isotope mixing models are highly sensitive to variation in discrimination factors. Ecol. Appl. 21, 1017-1023.

Borme, D., Tirelli, V., Brandt, S.B., Fonda Umani, S., Arneri, E., 2009. Diet of Engraulis encrasicolus in the northern Adriatic Sea (Mediterranean): ontogenetic changes and feeding selectivity. Mar. Ecol. Prog. Ser. 392, 193-209.

Brodeur, R.D., Suchman, C.L., Reese, D.C., Miller, T.W., Daly, E.A., 2008. Spatial overlap and trophic interactions between pelagic fish and large jellyfish in the northern California Current. Mar. Biol. 154, 649-659. 
Caut, S., Angulo, E., Courchamp, F., 2009. Variation in discrimination factors $(\triangle 15 \mathrm{~N}$ and $\triangle 13 \mathrm{C}$ ): the effect of diet isotopic values and applications for diet reconstruction. J. Appl. Ecol. $46,443-453$.

Certain, G., Ridoux, V., Van Canneyt, O., Bretagnolle, V., 2008. Delphinid spatial distribution and abundance estimates over the shelf of the Bay of Biscay. ICES J. Mar. Sci. 65, 656-666.

Certain, G., Masse, J., Van Canneyt, O., Petitgas, P., Doremus, G., Santos, M., Ridoux, V., 2011. Investigating the coupling between small pelagic fish and marine top predators using data collected from ecosystem-based surveys. Mar. Ecol. Progr. Ser. 422, 23-39.

Chouvelon, T., Spitz, J., Caurant, F., Mèndez-Fernandez, P., Chappuis, A., Laugier, F., Le Goff, E., Bustamante, P., 2012. Revisiting the use of $\delta^{15} \mathrm{~N}$ in meso-scale studies of marine food webs by considering spatio-temporal variations in stable isotopic signatures - The case of an open ecosystem: the Bay of Biscay (North-East Atlantic). Prog. Oceanogr. 101, 92-105.

Chouvelon, T., Spitz, J., Cherel, Y., Caurant, F., Sirmel, R., Mèndez-Fernandez, P., Bustamante, P., 2011. Inter-specific and ontogenic differences in $\delta^{13} \mathrm{C}$ and $\delta^{15} \mathrm{~N}$ values and $\mathrm{Hg}$ and $\mathrm{Cd}$ concentrations in cephalopods. Mar. Ecol. Progr. Ser. 433, 107-120.

Coiffec, G., Duhamel, E., Biseau, A., Danzart, M., 2006. Analyse des petits pélagiques, sardine et anchois, dans le Golfe de Gascogne. Ifremer, Lorient, $81 \mathrm{p}$.

Conley, W.J., Turner, J.T., 1985. Omnivory by the coastal marine copepods Centropages hamatus and Labidocera aestiva. Mar. Ecol. Progr. Ser. 21, 113-120.

Costalago, D., Navarro, J., Álvarez-Calleja, I., Palomera, I., 2012. Ontogenetic and seasonal changes in the feeding habits and trophic levels of two small pelagic fish species. Mar. Ecol. Prog. Ser. 460, 169-181.

Cunha, M.E., Garrido, S., Pissarra, J., 2005. The use of stomach fullness and colour indices to assess Sardina pilchardus feeding. J. Mar. Biol. Assoc. UK 85, 425-431.

Dalerum, F., Angerbjörn, A., 2005. Resolving temporal variation in vertebrate diets using naturally occuring stable isotopes. Oecologia 144, 647-658.

Dam, H.G., Lopes, R.M., 2003. Omnivory in the calanoid copepod Temora longicornis: feeding, egg production and egg hatching rates. J. Exp. Mar. Biol. Ecol. 292, 119-137.

De Niro, M.J., Epstein, S., 1977. Mechanism of carbon fractionation associated with lipid synthesis. Science 197, 261-263.

De Niro, M.J., Epstein, S., 1978. Influence of diet on the distribution of carbon isotopes in animals. Geochim. Cosmochim. Acta 42, 495-506.

De Niro, M.J., Epstein, S., 1981. Influence of diet on the distribution of nitrogen isotopes in animals. Geochim. Cosmochim. Acta 45, 341-351.

Espinoza, P., Bertrand, A., Van der Lingen, C.D., Garrido, S., Rojas de Mendiola, B., 2009. Diet of sardine (Sardinops sagax) in the northern Humboldt Current system and comparison with the diets of clupeoids in this and other eastern boundary upwelling systems. Prog. Oceanogr. 83, 242-250.

Feuchtmayr, H., Grey, J., 2003. Effect of preparation and preservation procedures on carbon and nitrogen stable isotope determinations from zooplankton. Rapid. Commun. Mass Spectrom. 17, 2605-2610. 
Fenchel, T., 1988. Marine Plankton Food Chains. Annu. Rev. Ecol. Syst. 19, 19-38.

Fraga, F., 1981. Upwelling of the Galician coast, Northwest Spain, in: Richards, F. (Ed), Coastal Upwelling. American Geophysical Union Washington, DC, pp. 176-182.

Fry, B., 1988. Food web structure on Georges Bank from stable C, N, and S isotopic compositions. Limnol. Oceanogr. 33,1182-1190.

Gannon, J.E., 1976. The effects of differential digestion rates of zooplankton by alewife, Alosa pseudoharengus, on determinations of selective feeding. T. Am. Fish Soc. 105, 89-95.

Hannides, C.C.S., Popp, B.N., Landry, M.R. and Graham, B.S., 2009. Quantification of zooplankton trophic position in the North Pacific Subtropical Gyre using stable nitrogen isotopes. Limnol. Oceanogr. 54, 50-61.

Hansen, B., Bjornsen, P.K., Hansen, P.J., 1994. The size ratio between planktonic predators and their prey. Limnol. Oceanogr. 39, 395-403.

Garrido, S., Marçalo, A., Zwolinski, J., Van der Lingen, C.D. 2007. Laboratory investigations on the effect of prey size and concentration on the feeding behaviour of Sardina pilchardus. Mar. Ecol. Prog. Ser. 330, 189-199.

Garrido, S., Rosa, R., Ben-Hamadou, R., Cunha, M.E., Chícharo, M.A., Van der Lingen, C.D., 2008. Spatio-temporal variability in fatty acid trophic biomarkers in stomach contents and muscle of Iberian sardine (Sardina pilchardus) and its relationship with spawning. Mar. Biol. 154, 1053-1065.

Hobson, K.A., 1999. Tracing origins and migration of wildlife using stable isotopes: a review. Oecologia 120, 314-326.

Hobson, K.A., Welch, H.E., 1992. Determination of trophic relationships within a high Arctic marine food web using $\delta^{13} \mathrm{C}$ and $\delta^{15} \mathrm{~N}$ analysis. Mar. Ecol. Prog. Ser. 84, 9-18.

ICES, 2010a. Report of the Working Group on Anchovy and Sardine (WGANSA). ICES WGANSA Report 2010, ICES, 289 p.

ICES, 2010b. Life-cycle spatial patterns of small pelagic fish in the Northeast Atlantic. ICES Cooperative Research Report, ICES, 94 p.

James, A.G., 1988. Are clupeid microphagists herbivorous or omnivorous? A review of the diets of some commercially important clupeids. S. Afr. J. Marine Sci. 7, 161-177.

James, A.G., Findlay, K.P., 1989. Effect of particle size and concentration on feeding behavior, selectivity and rates of food ingestion by the Cape anchovy Engraulis capensis. Mar. Ecol. Prog. Ser. 50, 275-294.

Kelly, J.F., 2000. Stable isotopes of carbon and nitrogen in the study of avian and mammalian trophic ecology. Can. J. Zool. 78, 1-27.

Kaehler, S., Pakhomov, E.A., 2001. Effects of storage and preservation on the $\delta^{13} \mathrm{C}$ and $\delta^{15} \mathrm{~N}$ signatures of selected marine organisms. Mar. Ecol. Prog. Ser. 219, 299-304.

Kleppel, G.S., Frazel, D., Pieper, R.E., Holliday, D.V., 1988. Natural diets of zooplankton off southern California. Mar. Ecol. Progr. Ser. 49, 231-241. 
Lassalle, G., Lobry, J., Le Loc'h, F., Bustamante, P., Certain, G., Delmas, D., Dupuy, C., Hily, C., Labry, C., Le Pape, O., Marquis, E., Petitgas, P., Pusineri, C., Ridoux, V., Spitz, J., Niquil, N., 2011. Lower trophic levels and detrital biomass control the Bay of Biscay continental shelf food web: implications for ecosystem management. Prog. Oceanogr. 91, 561-575.

Lefèvre, M., 1946. Sur les méthodes de pêche qualitative et quantitative du plancton. B. Fr. Pêche Piscic. 142, 21-29.

McCutchan, J.H.J., Lewis, W.M.J., Kendall, C., McGrath, C.C., 2003. Variation in trophic shift for stable isotope ratios of carbon, nitrogen, and sulfur. Oikos 102, 378-390.

Minagawa, M., Wada, E., 1984. Stepwise enrichment of ${ }^{15} \mathrm{~N}$ along food chains: further evidence and the relation between $\delta^{15} \mathrm{~N}$ and animal age. Geochim. Cosmochim. Acta 48, $1135-1140$.

Montoya, J.P., 2007. Natural abundance of $\mathrm{N}$ in marine planktonic ecosystems, in: Michener, R., Lajtha, K. (Eds.), Stable isotopes in ecology and environmental science. Blackwell Publishing Ltd, pp. 176-201.

Murry, B.A., Farrell, J.M., Teece, M.A., Smyntek, P.M., 2006. Effect of lipid extraction on the interpretation of fish community trophic relation ships determined by stable carbon and nitrogen isotopes. Can. J. Aquat. Sci. 63, 2167-2172.

Nikolioudakis, N., Isari, S., Pitta, P., Somarakis, S., 2012a. Diet of sardine Sardina pilchardus: an end-to-end" field study. Mar. Ecol. Prog. Ser. 453, 173-188.

Nikolioudakis, N., Palomera, I., Machias, A., Somarakis, S., 2012b. Diel feeding intensity and daily ration of the sardine Sardina pilchardus. Mar. Ecol. Prog. Ser. 437, 215-228.

Owens, N.J.P., 1987. Natural variations in ${ }^{15} \mathrm{~N}$ in the marine environment. Adv. Mar. Biol. 24, 389-451.

OSPAR, 2010. Quality Status Report 2010. OSPAR Commission, London, 176 p.

Paffenhöfer, G.A., Knowles, S.C., 1980. Omnivorousness in marine planktonic copepods. J. Plankton Res. 2, 355-365.

Parnell, A.C., Inger, R., Bearhop, S., Jackson, A.L., 2010. Source partitioning using stable isotopes: coping with too much variation. Plos One 5: e9672, doi:10.1371/journal.pone.0009672.

Peters, R.H., 1983. The ecological implications of body size. Cambridge: Cambridge University Press, 329 pp.

Peterson, B.J., 1999. Stable isotopes as tracers of organic matter input and transfer in benthic food webs: a review. Acta Oecol. 20, 479-487.

Peterson, B.J., Fry, B., 1987. Stable isotopes in ecosystem studies. Annu. Rev. Ecol. Syst. 18, 293- 320.

Phillips, D.L., 2001. Mixing models in analyses of diet using multiple stable isotopes: a critique. Oecologia 127, 166-170.

Phillips, D.L., Newsome, S.D., Gregg, J.W., 2005. Combining sources in stable isotope mixing models: alternative methods. Oecologia 144, 520-527. 
Pinnegar, J.K., Polunin, N.V.C., 1999. Differential fractionation of $\delta^{13} \mathrm{C}$ and $\delta^{15} \mathrm{~N}$ among fish tissues: implications for the study of trophic interactions. Funct. Ecol. 13, 225-231.

Platt, T., Rao, D.V.S., Irwin, B., 1983. Photosynthesis of picoplankton in the oligotrophic ocean. Nature 301, 702-704.

Plounevez, S., Champalbert, G., 1999. Feeding behaviour and trophic environment of Engraulis encrasicolus (L.) in the Bay of Biscay. Estuar. Coast. Shelf S. 49, 177-191.

Post, D.M., 2002. Using stable isotopes to estimate trophic position: models, methods and assumptions. Ecology 83, 703-718.

Post, D.M., Layman, C.A., Arrington, D.A., Takimoto, G., Quattrochi, J., Montaña, C.G., 2007. Getting to the fat of the matter: models, methods, and assumptions for dealing with lipids in stable isotope analyses. Oecologia 152, 179-189.

R Development Core Team, 2011. R: a language and environment for statistical computing. R Foundation for Statistical Computing, Vienna, www.R-project.org.

Raab, K., Nagelkerke, L.A.J., Boerée, C., Rijnsdorp, A.D., Temming, A., Dickey-Collas, M., 2011. Anchovy Engraulis encrasicolus diet in the North and Baltic Seas. J. Sea. Res. 65, $131-140$

Radin, N.S., 1981. Extraction of tissue lipids with a solvent of low toxicity. Method. Enzymol. 72, 5-7.

Richardson A.J., Walne, A.W., John, A.W.G., Jonas, T.D., Lindley, J.A., Sims, D.W., Stevens, D., Witt, M., 2006. Using continuous plankton recorder data. Prog. Oceanogr. 68, $27-74$.

Rose, M., 1933. Copépodes pélagiques. Faune de France, 26, Paris.

Sarakinos, H.C., Johnson, M.L., Vander Zanden, M.J., 2002. A synthesis of tissuepreservation effects on carbon and nitrogen stable isotope signatures. Can. J. Zool. 80, 381387.

Schell, D.M., Barnett, B.A., Vinette, K.A., 1998. Carbon and nitrogen isotope ratios in zooplankton of the Bering, Chukchi and Beaufort Seas. Mar. Ecol. Prog. Ser. 162, 11-23.

Schlechtriem, C., Focken, U., Becker, K., 2003. Effect of different lipid extraction methods on $\delta^{13} \mathrm{C}$ of lipid and lipid-free fractions of fish and different fish feeds. Isot. Environ. Health $\mathrm{S}$., 39: $135-140$.

Sever, T.M., Bayhan, B., Taskavak, E., 2005. A preliminary study on the feeding regime of European pilchard (Sardina pilchardus Walbaum 1792) in Izmir Bay, Turkey, Eastern Aegean Sea. Naga 28, 41-48.

Smedes, F., 1999. Determination of total lipid using non-chlorinated solvents. Analyst, 124: 1711-1718.

Smyntek, P.M., Teece, M.A., Schulz, K.L., Thackeray, S.J., 2007. A standard protocol for stable isotope analysis of zooplankton in aquatic food web research using mass balance correction models. Limnol. Oceanogr. 52, 2135-2146. 
Sotiropoulos, M.A., Tonn, W.M., Wassenaar, L.I., 2004. Effects of lipid extraction on stable carbon and nitrogen isotope analyses of fish tissues: potential consequences for food web studies. Ecol. Freshw. Fish 13, 155-160.

Spitz, J., Quéro, J.C., 2008. Observations ichtyologiques de la faune bathypélagique du canyon du Cap Ferret. Ann. Soc. Sci. nat. Charente-Marit. 9, 811-814.

Stergiou, K.I., Karpouzi, V.S., 2002. Feeding habits and trophic levels of Mediterranean fish. Rev. Fish Biol. Fisher. 11, 217-254.

Sweeting, C.J., Polunin, N.V.C., Jennings, S., 2004. Tissue and fixative dependent shifts of $\delta^{13} \mathrm{C}$ and $\delta^{15} \mathrm{~N}$ in preserved ecological material. Rapid. Commun. Mass Spectrom. 18, 25872592.

Sweeting, C.J., Barry, J.T., Barnes, C., Polunin, N.V.C., Jennings, S., 2007a. Effects of body size and environment on diet-tissue $\delta^{15} \mathrm{~N}$ fractionation in fishes. J. Exp. Mar. Biol. Ecol. 340, $1-10$.

Sweeting, C.J., Barry, J.T., Barnes, C., Polunin, N.V.C., Jennings, S., 2007b. Effects of body size and environment on diet-tissue $\delta^{13} \mathrm{C}$ fractionation in fishes. J. Exp. Mar. Biol. Ecol. 352, 165-176.

Tieszen, L.L., Boutton, T.W., Tesdahl, K.G., Slade, N.A., 1983. Fractionation and turnover of stable carbon isotopes in animal tissues: implications for $\delta^{13} \mathrm{C}$ analysis of diet. Oecologia 57, 32-37.

Trenkel, V.M., Berthelé, O., Lorance, P., Bertrand, J., Brind'Amour, A., Cochard, M.L., Coppin, F., Léauté, J.P., Mahé, J.C., Morin, J., Rochet, M.J., Salaun, M., Souplet, A., Vérin, Y., 2009. Atlas des grands invertébrés et poissons observés par les campagnes scientifiques. Bilan 2008. Ifremer, Nantes, EMH: 09-003, 100 pp.

Trueman, C.N., McGill, R.A.R., Guyard, P.H., 2005. The effect of growth rate on tissue-diet isotopic spacing in rapidly growing animals. An experimental study with Atlantic salmon (Salmo salar). Rapid. Commun. Mass Spectrom. 19, 3239-3247.

Tudela, S., Palomera, I., 1997. Trophic ecology of the European anchovy Engraulis encrasicolus in the Catalan Sea (northwest Mediterranean). Mar. Ecol. Prog. Ser. 160, 121134.

Tudela, S., Palomera, I., Quílez, G., 2002. Feeding of anchovy Engraulis encrasicolus larvae in the north-west Mediterranean. J. Mar. Biol. Assoc. UK 82, 349-350.

Uriarte, A., Prouzet, P., Villamor, B., 1996. Bay of Biscay and Ibero Atlantic anchovy populations and their fisheries. Sci. Mar. 60, 237-255.

Valdés, L., Moral, M., 1998. Time-series analysis of copepod diversity and species richness in the southern Bay of Biscay off Santander, Spain, in relation to environmental conditions. ICES J. Mar. Sci. 55, 783-792.

Vanderklift, M.A., Ponsard, S., 2003. Source of variation in consumer-diet $\delta^{15} \mathrm{~N}$ enrichment: a meta-analysis. Oecologia 136, 169-182.

Van der Lingen, C.D., 1994. Effect of particle size and concentration on the feeding behaviour of adult pilchard Sardinops sagax. Mar. Ecol. Prog. Ser. 109,1-13. 
Van der Lingen, C.D., Bertrand, A., Bode, A., Brodeur, R., Cubillos, L., Espinoza, P., Friedland, K., Garrido, S., Irigoien, X., Möllman, C., Rodriguez-Sanchez, R., Tanaka, H. and Temming, A., 2009. Chapter 7. Trophic dynamics, in: Checkley, D.M., Roy, C., Alheit, J., Oozeki, Y. (Eds.), Climate change and small pelagic fish. GLOBEC Project Office, Plymouth (UK), pp. 112-157.

Van der Lingen, C.D., Hutchings, L., Field, J., 2006. Comparative trophodynamics of anchovy Engraulis encrasicolus and sardine Sardinops sagax in the southern Benguela: are species alternations between small pelagic fish trophodynamically mediated? Afr. J. Marine Sci. 28, 465-477.

Vander Zanden, M.J., Rasmussen, J.B., 2001. Variation in $\delta^{15} \mathrm{~N}$ and $\delta^{13} \mathrm{C}$ trophic fractionation: implications for aquatic food web studies. Limnol. Oceanogr. 46, 2061-2066. 
Table 1: Relative abundances (in \%) of the dominant species analysed for $\delta^{13} \mathrm{C}$ and $\delta^{15} \mathrm{~N}$ values (i.e., species or groups of species contributing to more than $5 \%$ to both total abundance in number and in biomass, and likely to be part of sardines' and anchovies' diet; see section 2.1). Some small taxa (i.e., copepod nauplii in C1, Oithona sp. in SI1 and SI3) contributing to more than $10 \%$ to the total abundance in number (but not in biomass because of their small size) have been included and analysed as well (see section 2.1). The total contribution of copepods (in brackets and in \%) and of others organisms (i.e., non-copepod fraction) within each of the 13 stations considered for the study is also indicated. $\mathrm{C}=$ Coastal; $\mathrm{Sh}=\mathrm{Shelf}$; $\mathrm{SI}=$ Slope; the number corresponds to the transect from the northern (transect 1) to the southern part (transect 5) of the Bay of Biscay area (see Fig. 1). Within each station, organisms are classified following their relative abundance in number.

Species analysed for isotope values and
contribution of copepods and of other
organisms to the total abundance in number
I in biomass (in \%)

\section{Relative abundance of analysed species and contribution of these species (in brackets) to the total abundance in number / in biomass (in} $\%)$

C1 Copepods $(68 / 84)$

$\begin{array}{rc}\text { Copepod nauplii } & 19 / 1 \\ \text { Euterpina sp. } & 18 / 6 \\ \text { Temora sp. } & 13 / 28 \\ \text { ermined Calanoid } & 8 / 33\end{array}$

Medium undetermined Calanoid

Sh1 Copepods $(84 / 65)$

Calanus helgolandicus

Temora sp.

Medium undetermined Calanoid

$17 / 6$

$17 / 11$

Other planktonic organisms (16/35)

SI1 Copepods (92 / 99)

$$
\begin{array}{rc}
\text { Calanus helgolandicus } & 48 / 83 \\
\text { Oithona sp. } & 17 / 2 \\
\text { Medium undetermined Calanoid } & 13 / 9
\end{array}
$$

Other planktonic organisms (8/1)

C2 Copepods (82 / 79\%)

Temora sp.

Other planktonic organisms (18 / 21\%)

Sh2 Copepods (99/98)

Calanus helgolandicus

Other planktonic organisms (1 / 2)

SI2 Copepods (99 / nearly 100)

Medium undetermined Calanoid

Other planktonic organisms ( 1 / nearly 0 ) 


\begin{tabular}{|c|c|c|}
\hline Station & $\begin{array}{c}\text { Species analysed for isotope values and } \\
\text { contribution of copepods and of other } \\
\text { organisms to the total abundance in number } \\
\text { / in biomass (in \%) }\end{array}$ & $\begin{array}{l}\text { Relative abundance } \\
\text { of analysed species } \\
\text { and contribution of } \\
\text { these species (in } \\
\text { brackets) to the total } \\
\text { abundance in } \\
\text { number / in biomass } \\
\text { (in \%) }\end{array}$ \\
\hline C3 & $\begin{array}{l}\text { Copepods (77 / 80) } \\
\qquad \begin{array}{l}\text { Oncaea sp. } \\
\text { Temora sp. } \\
\text { Acartia sp. } \\
\text { Oithona sp. }\end{array} \\
\text { Other planktonic organisms (23 / 20) }\end{array}$ & $\begin{array}{c}29 / 16 \\
15 / 36 \\
13 / 15 \\
11 / 6 \\
(68 / 73)\end{array}$ \\
\hline Sh3 & $\begin{array}{l}\text { Copepods (50 / } 51) \\
\text { Medium undetermined Calanoid } \\
\text { Other planktonic organisms (50/49) } \\
\text { Evadne/Podon sp. }\end{array}$ & $\begin{array}{c}18 / 25 \\
36 / 11 \\
(54 / 36)\end{array}$ \\
\hline SI3 & $\begin{array}{l}\text { Copepods (96 / 99) } \\
\text { Medium undetermined Calanoid } \\
\text { Oithona sp. }\end{array}$ & $\begin{array}{c}44 / 73 \\
32 / 22 \\
11 / 1 \\
(87 / 96)\end{array}$ \\
\hline C4 & $\begin{array}{l}\text { Copepods }(21 / 32) \\
\text { Acartia sp. } \\
\text { Other planktonic organisms }(79 / 68)\end{array}$ & $\begin{array}{c}8 / 9 \\
7 / 15 \\
(15 / 24)\end{array}$ \\
\hline SI4 & $\begin{array}{r}\text { Copepods (95/99) } \\
\text { Medium undetermined Calanoid } \\
\text { Acartia sp. } \\
\text { Calanus helgolandicus } \\
\text { Other planktonic organisms (5/ 1) }\end{array}$ & $\begin{array}{l}41 / 37 \\
26 / 6 \\
25 / 54 \\
(92 / 97)\end{array}$ \\
\hline Sh5 & $\begin{array}{l}\text { Copepods (95 / 93) } \\
\qquad \begin{array}{r}\text { Acartia sp. } \\
\text { Medium undetermined Calanoid } \\
\text { Temora sp. }\end{array} \\
\text { Other planktonic organisms (5 / 7) }\end{array}$ & $\begin{array}{l}35 / 17 \\
23 / 42 \\
22 / 22 \\
(80 / 81)\end{array}$ \\
\hline SI5 & $\begin{array}{l}\text { Copepods (96 / 96) } \\
\text { Acartia sp. } \\
\text { Calanus helgolandicus } \\
\text { Other planktonic organisms (4 / 4) }\end{array}$ & $\begin{array}{l}33 / 10 \\
19 / 56 \\
(52 / 66)\end{array}$ \\
\hline
\end{tabular}


Table 2: Summary of sampling locations and range of $\delta^{13} \mathrm{C}$ and $\delta^{15} \mathrm{~N}$ values (Mean \pm Standard Deviation, minimum and maximum, in \%o) for the different pelagic compartments and species analysed in this study. Within the mesozooplanktonic compartment, 34 entities -species-station" were analysed in total. Values presented for plankton are corrected values for the preservation effect and/or for lipid content for consistency of treatment between prey and predators (i.e., fish samples were kept frozen and delipidated with cyclohexane; see sections 2.2 and 3.1 ). $\mathrm{C}=$ Coastal; $\mathrm{Sh}=$ Shelf; $\mathrm{SI}=$ Slope; the number corresponds to the transect from the northern (transect 1 ) to the southern part (transect 5 ) of the Bay of Biscay area (see Fig. 1).

\begin{tabular}{|c|c|c|c|c|c|c|c|}
\hline Species & $\begin{array}{l}\text { Stations where species were } \\
\text { dominant and analysed } \\
\text { (for mesozooplankton) }\end{array}$ & Mean \pm SD & ${ }^{3} \mathrm{C}_{\text {min }}$ & $\max$ & Mean \pm SD & $\stackrel{\delta^{15} \mathrm{~N}}{\min }$ & $\max$ \\
\hline \multicolumn{8}{|l|}{$\begin{array}{r}\text { Mesozooplankton } \\
\text { Copepoda }\end{array}$} \\
\hline Acartia sp. & C2, C3, C4, SI4, Sh5, SI5 & $-20.4 \pm 0.5$ & -21.1 & -19.9 & $6.8 \pm 1.0$ & 5.7 & 8.6 \\
\hline Calanus helgolandicus & Sh1, SI1, Sh2, SI2, SI3, SI4, SI5 & $-21.3 \pm 0.9$ & -22.2 & -19.7 & $7.0 \pm 0.7$ & 6.4 & 8.3 \\
\hline Medium und. Calanoids & $\begin{array}{c}\text { C1, Sh1, SI1, SI2, Sh3, SI3, SI4, } \\
\text { Sh5 }\end{array}$ & $-20.5 \pm 0.9$ & -21.9 & -19.6 & $5.7 \pm 1.4$ & 4.4 & 8.0 \\
\hline $\begin{array}{l}\text { Oithona sp. } \\
\text { Oncaea sp. }\end{array}$ & $\begin{array}{c}\mathrm{SI}, \mathrm{C} 3, \mathrm{SI} 3 \\
\mathrm{C} 3\end{array}$ & $\begin{array}{l}-20.5 \pm 0.8 \\
-20.2\end{array}$ & -21.3 & $\begin{array}{l}-19.7 \\
-20.2\end{array}$ & $\begin{array}{l}4.6 \pm 2.1 \\
7.6\end{array}$ & $\begin{array}{ll}3.2 \\
-\end{array}$ & $\begin{array}{l}7.0 \\
7.6\end{array}$ \\
\hline Temora sp. & C1, Sh1, C2, C3, C4, Sh5 & $-19.5 \pm 0.3$ & -19.8 & -19.2 & $6.3 \pm 0.8$ & 5.1 & 7.3 \\
\hline Euterpina sp. & C1 & -20.2 & - & -20.2 & 6.7 & - & 6.7 \\
\hline Copepod nauplii & $\mathrm{C} 1$ & -19.9 & - & -19.9 & 6.6 & - & 6.6 \\
\hline $\begin{array}{c}\text { Cladocera } \\
\text { Evadne / Podon sp. }\end{array}$ & Sh3 & -19.0 & - & -19.0 & 6.6 & - & 6.6 \\
\hline \multicolumn{8}{|l|}{ Fish } \\
\hline Sardina pilchardus & - & $-17.8 \pm 0.3$ & -18.4 & -17.2 & $10.9 \pm 0.5$ & 10.0 & 12.2 \\
\hline Engraulis encrasicolus & - & $-18.4 \pm 0.4$ & -19.3 & -17.9 & $9.8 \pm 0.6$ & 8.8 & 11.1 \\
\hline
\end{tabular}


Table 3: $\delta^{13} \mathrm{C}$ and $\delta^{15} \mathrm{~N}$ values (Mean \pm Standard Deviation in \%) of the mesozooplanktonic prey groups defined by hierarchical cluster analysis and used in mixing models. Values presented are corrected values for the preservation effect and/or for lipid content, for consistency of treatment between prey and predators (i.e., fish samples were kept frozen and delipidated with cyclohexane; see sections 2.2 and 3.1 ). Main reference for the average size of organisms (especially copepods): Rose, 1933 and Richardson et al., 2006.

\begin{tabular}{|c|c|c|c|c|c|c|c|}
\hline Group & $\begin{array}{l}\text { Relative size of } \\
\text { organisms }\end{array}$ & $\begin{array}{l}\text { Range of } \\
\text { sizes } \\
(\mathrm{mm})\end{array}$ & Zone & Area & $\begin{array}{l}\text { Species forming the group } \\
\text { and associated stations }\end{array}$ & $\begin{array}{c}\delta^{13} \mathrm{C} \\
\text { Mean } \pm \text { SD }\end{array}$ & $\begin{array}{c}\delta^{15} \mathrm{~N} \\
\text { Mean } \pm \text { SD }\end{array}$ \\
\hline 1 & Small to medium & $0.7-1.9$ & Slope & North & $\begin{array}{l}\text { Oithona sp. (SI1) } \\
\text { Medium und. Calanoid (SI1, SI2) }\end{array}$ & $-20.3 \pm 0.4$ & $4.2 \pm 0.6$ \\
\hline 2 & Medium & $1.4-1.9$ & $\begin{array}{l}\text { Coast to } \\
\text { shelf }\end{array}$ & Central to north & $\begin{array}{l}\text { Temora sp. (C2) } \\
\text { Medium und. Calanoid (Sh3) }\end{array}$ & $-19.4 \pm 0.3$ & $4.9 \pm 0.3$ \\
\hline 3 & Small to medium & $0.7-1.9$ & Slope & Central to south & $\begin{array}{l}\text { Oithona sp. }(\mathrm{SI} 3) \\
\text { Medium und. Calanoid }(\mathrm{SI} 3, \mathrm{SI} 4)\end{array}$ & $-21.7 \pm 0.3$ & $4.3 \pm 1.0$ \\
\hline 4 & Small to medium & $0.2-1.9$ & $\begin{array}{l}\text { Coast to } \\
\text { shelf }\end{array}$ & North & $\begin{array}{l}\text { Copepod nauplii (C1) } \\
\text { Euterpina sp. (C1) } \\
\text { Acartia sp. (C2) } \\
\text { Temora sp. (C1, Sh1) } \\
\text { Medium und. Calanoid (C1, Sh1) }\end{array}$ & $-19.8 \pm 0.2$ & $7.0 \pm 0.6$ \\
\hline 5 & Large & 2.9 & $\begin{array}{l}\text { Shelf to } \\
\text { slope }\end{array}$ & North & $\begin{array}{l}\text { C. helgolandicus (Sh1, Sh2, SI1, } \\
\text { SI2) }\end{array}$ & $-20.6 \pm 0.7$ & $7.1 \pm 0.9$ \\
\hline 6 & Large & 2.9 & Slope & Central to south & C. helgolandicus (SI3, SI4, SI5) & $-22.2 \pm 0.1$ & $6.8 \pm 0.4$ \\
\hline 7 & Small to medium & $1.0-1.9$ & $\begin{array}{l}\text { Coast to } \\
\text { slope }\end{array}$ & South & $\begin{array}{l}\text { Acartia sp. (Sh5, SI4, SI5) } \\
\text { Temora sp. (C4, Sh5) } \\
\text { Medium und. Calanoid (Sh5) }\end{array}$ & $-20.4 \pm 0.7$ & $6.2 \pm 0.6$ \\
\hline 8 & Small to medium & $0.7-1.4$ & $\begin{array}{l}\text { Coast to } \\
\text { shelf }\end{array}$ & Central to south & $\begin{array}{l}\text { Oithona sp. (C3) } \\
\text { Oncaea sp. (C3) } \\
\text { Evadne / Podon sp. (Sh3) } \\
\text { Acartia sp. (C3, C4) } \\
\text { Temora sp. (C3) }\end{array}$ & $-19.8 \pm 0.5$ & $7.2 \pm 0.9$ \\
\hline
\end{tabular}


Table 4: Summary of estimated contributions (mean values) of mesozooplanktonic prey groups in the diet of European sardine Sardina pilchardus and European anchovy Engraulis encrasicolus from the four different mixing models applied with different Trophic Enrichment Factors (TEFs: $\Delta \delta^{13} \mathrm{C}$ and $\left.\Delta \delta^{15} \mathrm{~N}\right)$ taken in the literature (i.e., sensitivity analysis). Values for groups of prey contributing on average to more than $5 \%$ in the diet of each species, when the four models are considered, are in bold. Groups of prey contributing on average for more than $10 \%$ in the diet of both species are in bold.

\begin{tabular}{|c|c|c|c|c|c|}
\hline \multirow[b]{2}{*}{$\begin{array}{c}\text { Model applied } \\
\text { References for TEFs }\end{array}$} & \multicolumn{5}{|c|}{ Sardina pilchardus } \\
\hline & $\begin{array}{c}\text { Model } 1 \\
\text { Post } 2002\end{array}$ & $\begin{array}{c}\text { Model } 2 \\
\text { Sweeting et } \\
\text { al. 2007ab }\end{array}$ & $\begin{array}{c}\text { Model } 3 \\
\text { Pinnegar } \\
\text { and Polunin } \\
1999 \\
\end{array}$ & $\begin{array}{l}\text { Model } 4 \\
\text { Trueman et } \\
\text { al. } 2005\end{array}$ & Mean \pm SD \\
\hline $\begin{array}{l}\Delta \delta^{13} \mathrm{C} \\
\Delta \delta^{15} \mathrm{~N}\end{array}$ & $\begin{array}{l}0.4 \pm 1.3 \\
3.4 \pm 1.0\end{array}$ & $\begin{array}{l}1.7 \pm 1.1 \\
3.2 \pm 1.3\end{array}$ & $\begin{array}{l}2.5 \pm 0.1 \\
3.3 \pm 0.2\end{array}$ & $\begin{array}{l}2.1 \pm 0.1 \\
2.3 \pm 0.3\end{array}$ & \\
\hline $\begin{array}{l}\text { Group of prey } \\
\text { 1. Small- to medium-sized organisms / slope / northern part } \\
\text { 2. Medium-sized organisms / coast to shelf / central to northern part } \\
\text { 3. Small- to medium-sized organisms / slope / central to southern part } \\
\text { 4. Small- to medium-sized organisms / coast to shelf / northern part } \\
\text { 5. Large organisms / shelf to slope / northern part } \\
\text { 6. Large organisms / slope / central to southern part } \\
\text { 7. Small- to medium-sized organisms / coast to slope / southern part } \\
\text { 8. Small- to medium-sized organisms / coast to shelf / central to southern part }\end{array}$ & $\begin{array}{c}1.2 \pm 1.0 \\
2.1 \pm 1.8 \\
0.9 \pm 0.8 \\
34.5 \pm 12.5 \\
10.3 \pm 8.3 \\
2.1 \pm 2.0 \\
3.3 \pm 3.0 \\
45.6 \pm 11.8\end{array}$ & $\begin{array}{c}1.3 \pm 1.2 \\
3.0 \pm 2.7 \\
0.9 \pm 0.8 \\
38.0 \pm 9.3 \\
9.6 \pm 5.9 \\
1.7 \pm 1.4 \\
3.8 \pm 3.2 \\
41.7 \pm 8.3\end{array}$ & $\begin{array}{c}1.1 \pm 1.0 \\
1.3 \pm 1.2 \\
1.1 \pm 1.0 \\
16.4 \pm 10.6 \\
28.9 \pm 11.7 \\
10.7 \pm 4.5 \\
3.7 \pm 3.4 \\
36.8 \pm 13.1\end{array}$ & $\begin{array}{c}1.7 \pm 1.6 \\
3.1 \pm 3.0 \\
1.3 \pm 1.2 \\
26.5 \pm 12.7 \\
9.9 \pm 6.5 \\
2.3 \pm 1.8 \\
4.5 \pm 4.1 \\
50.7 \pm 12.8\end{array}$ & $\begin{array}{c}1.3 \pm 0.3 \\
2.4 \pm 0.8 \\
1.1 \pm 0.2 \\
28.9 \pm 9.6 \\
14.7 \pm 9.5 \\
4.2 \pm 4.3 \\
3.8 \pm 0.5 \\
\mathbf{4 3 . 7} \pm \mathbf{5 . 9}\end{array}$ \\
\hline & \multicolumn{5}{|c|}{ Engraulis encrasicolus } \\
\hline $\begin{array}{l}\text { 1. Small- to medium-sized organisms / slope / northern part } \\
\text { 2. Medium-sized organisms / coast to shelf / central to northern part } \\
\text { 3. Small- to medium-sized organisms / slope / central to southern part } \\
\text { 4. Small- to medium-sized organisms / coast to shelf / northern part } \\
\text { 5. Large organisms / shelf to slope / northern part } \\
\text { 6. Large organisms / slope / central to southern part } \\
\text { 7. Small- to medium-sized organisms / coast to slope / southern part } \\
\text { 8. Small- to medium-sized organisms / coast to shelf / central to southern part }\end{array}$ & $\begin{aligned} 4.0 & \pm 3.5 \\
26.0 & \pm 7.2 \\
1.7 & \pm 1.6 \\
27.9 & \pm 11.4 \\
6.0 & \pm 5.4 \\
1.7 & \pm 1.7 \\
6.0 & \pm 5.4 \\
26.7 & \pm 10.2\end{aligned}$ & $\begin{array}{l}5.5 \pm 3.8 \\
12.5 \pm 5.3 \\
3.4 \pm 2.6 \\
23.1 \pm 6.7 \\
15.1 \pm 6.2 \\
6.4 \pm 3.7 \\
12.0 \pm 6.2 \\
22.0 \pm 6.2\end{array}$ & $\begin{array}{r}5.2 \pm 4.0 \\
4.9 \pm 4.0 \\
8.2 \pm 5.2 \\
10.7 \pm 7.7 \\
19.3 \pm 11.1 \\
28.5 \pm 6.2 \\
11.6 \pm 8.5 \\
11.6 \pm 7.8\end{array}$ & $\begin{aligned} 1.4 & \pm 1.3 \\
1.7 & \pm 1.6 \\
1.5 & \pm 1.4 \\
15.6 & \pm 10.3 \\
30.1 & \pm 13.3 \\
15.9 & \pm 5.3 \\
4.8 & \pm 4.6 \\
29.0 & \pm 12.5\end{aligned}$ & $\begin{array}{c}4.0 \pm 1.9 \\
11.3 \pm 10.8 \\
3.7 \pm 3.1 \\
19.3 \pm 7.7 \\
17.6 \pm 10.0 \\
13.1 \pm 11.8 \\
8.6 \pm 3.7 \\
22.3 \pm 7.7\end{array}$ \\
\hline
\end{tabular}




\section{Figures}

Fig. 1: Map of the study area (Bay of Biscay) with transects realised from the coastline to the slope in spring 2010 (PELGAS survey) and with the 13 stations selected for plankton sampling. Trawls of fish sampling are also indicated. $\mathrm{T}=$ Transect; $\mathrm{C}=\mathrm{Coast} ; \mathrm{Sh}=$ Shelf; $\mathrm{SI}$ $=$ Slope.

Fig. 2: Relationships between the two replicates analysed for stable isotope ratios, both for identified organisms and for assemblages.

Fig. 3: Assessment of the $\mathrm{C} / \mathrm{N}$ ratio as a potentially good predictor of observed changes in isotope values when lipids are removed: relationships between $\mathrm{C} / \mathrm{N}$ ratios of untreated sample (proxy of lipid content) and mean difference in $\delta^{13} \mathrm{C}$ and $\delta^{15} \mathrm{~N}$ values (absolute value) between delipidated and untreated samples for mesozooplanktonic assemblages and the copepod species Calanus helgolandicus.

Fig. 4: Assessment of preservation and delipidation effects for mesozooplanktonic assemblages: relationships between mean $\delta^{13} \mathrm{C}$ and $\delta^{15} \mathrm{~N}$ values (in \%o of $70 \%$ ethanol preserved bulk samples vs. frozen preserved bulk samples (conservation effect assessment), and between frozen preserved delipidated samples vs. frozen preserved bulk samples (delipidation effect assessment). The equation of the regression line used for further correction of identified species $\delta^{13} \mathrm{C}$ and $\delta^{15} \mathrm{~N}$ values (see section 3.1), and the squared Pearson correlation coefficient are given for each relationship. The correspondence line 1:1 is also indicated.

Fig. 5: Illustration of intra-station variability of mesozooplanktonic $\delta^{13} \mathrm{C}$ and $\delta^{15} \mathrm{~N}$ values (in \%o) with the example of five different stations: C1 = Coast 1 , Sh1 = Shelf 1 , SI 1 = Slope 1 , SI3 = Slope 3, SI4 = Slope 4. For three out of the five stations (i.e., SI1, SI3, SI4), the value of the undetermined mesozooplanktonic assemblage is also given, for comparison of $\delta^{13} \mathrm{C}$ and $\delta^{15} \mathrm{~N}$ values with values of identified organisms. These three stations correspond to stations where copepods represented $\geq 90 \%$ of the total abundance (TA) both in number and biomass, and wherein at least thre dominant species of copepods representing $\geq 90 \%$ of the copepod abundance in biomass were analysed for isotope ratios (Table 1). $\delta^{13} \mathrm{C}$ and $\delta^{15} \mathrm{~N}$ values presented are corrected for preservation effect and/or for lipids effect for consistency of treatment between prey and predators (see sections 2.2 and 3.1).

Fig. 6: Spatial (north-south and coast-slope) $\delta^{13} \mathrm{C}$ and $\delta^{15} \mathrm{~N}$ values (in \%o) variability within the mesozooplanktonic species $C$. helgolandicus and Acartia sp. One point represents the mean value of two replicates for one species in one station. $\mathrm{C} 4=$ Coast $4, \mathrm{SI} 1=$ Slope 1 , $\mathrm{SI} 2=$ Slope $2, \mathrm{SI} 3=$ Slope $3, \mathrm{SI} 4=$ Slope $4, \mathrm{SI} 5=$ Slope $5 . \delta^{13} \mathrm{C}$ and $\delta^{15} \mathrm{~N}$ values presented are corrected for preservation effect and/or for lipids effect for consistency of treatment between prey and predators (see sections 2.2 and 3.1).

Fig. 7: Groups of mesozooplanktonic prey obtained by hierarchical cluster analysis and then used in mixing models, based on $\delta^{13} \mathrm{C}$ and $\delta^{15} \mathrm{~N}$ values, average size and geographical coordinates of each entity « species-station » (34 in total) analysed for isotope ratios.

Fig. 8: $\delta^{13} \mathrm{C}$ and $\delta^{15} \mathrm{~N}$ values (mean $\pm \mathrm{SD}$, in \%o) for European sardine Sardina pilchardus and European anchovy Engraulis encrasicolus, depending on the sampling location (north vs. south of the Bay of Biscay). $* * * "$ indicates significant difference between the species (Student t-test and Wilcoxon test for $\delta^{13} \mathrm{C}$ and $\delta^{15} \mathrm{~N}$ values respectively, both $\mathrm{p}<0.001$ ). A.S." indicates non-significant difference between individuals sampled in the northern part and those sampled in the southern part of the Bay of Biscay area within each species (Student t-test or Wilcoxon test for $\delta^{13} \mathrm{C}$ and $\delta^{15} \mathrm{~N}$ values, $\mathrm{p}>0.05$ ). 


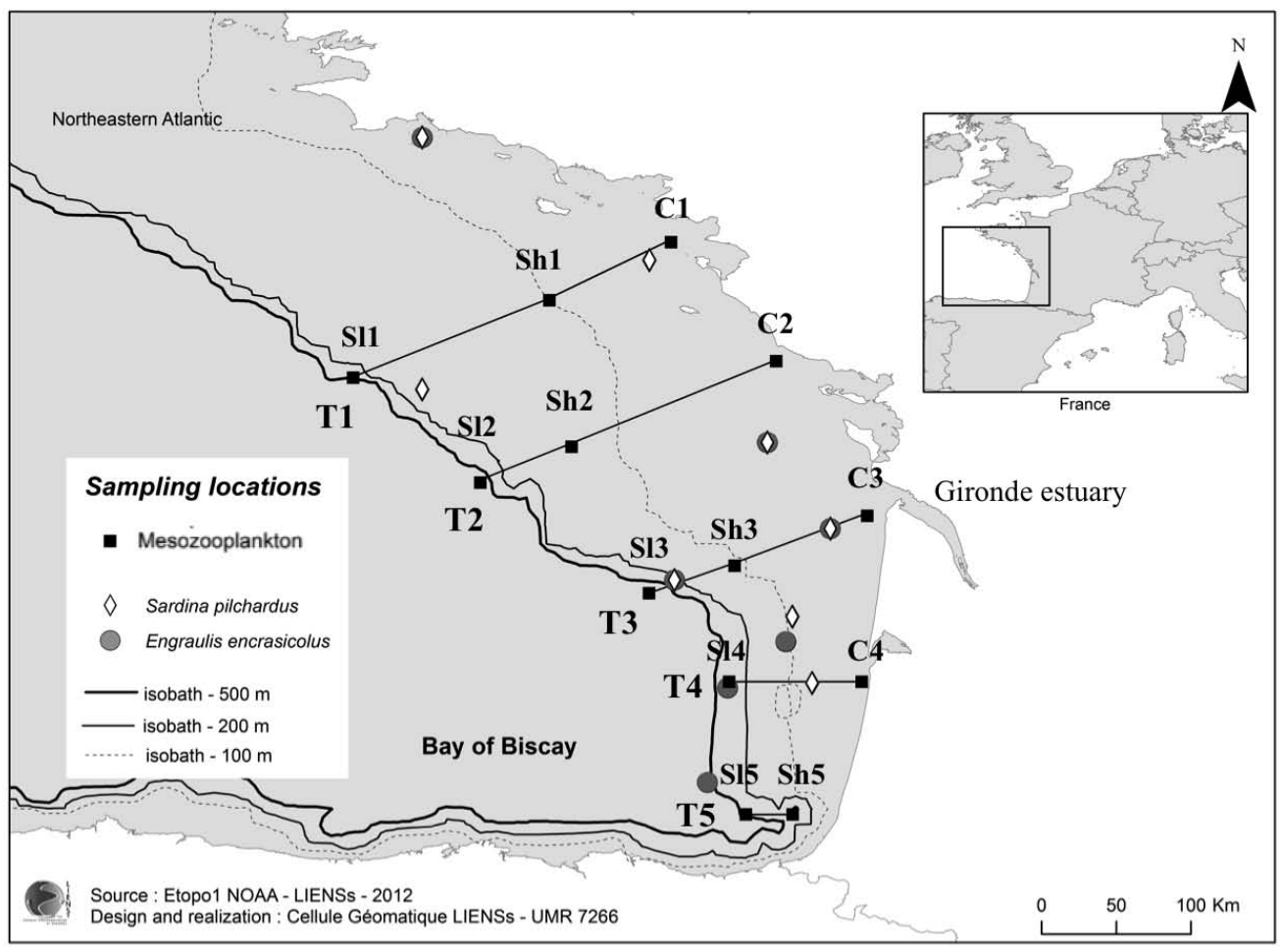

Figure 1 

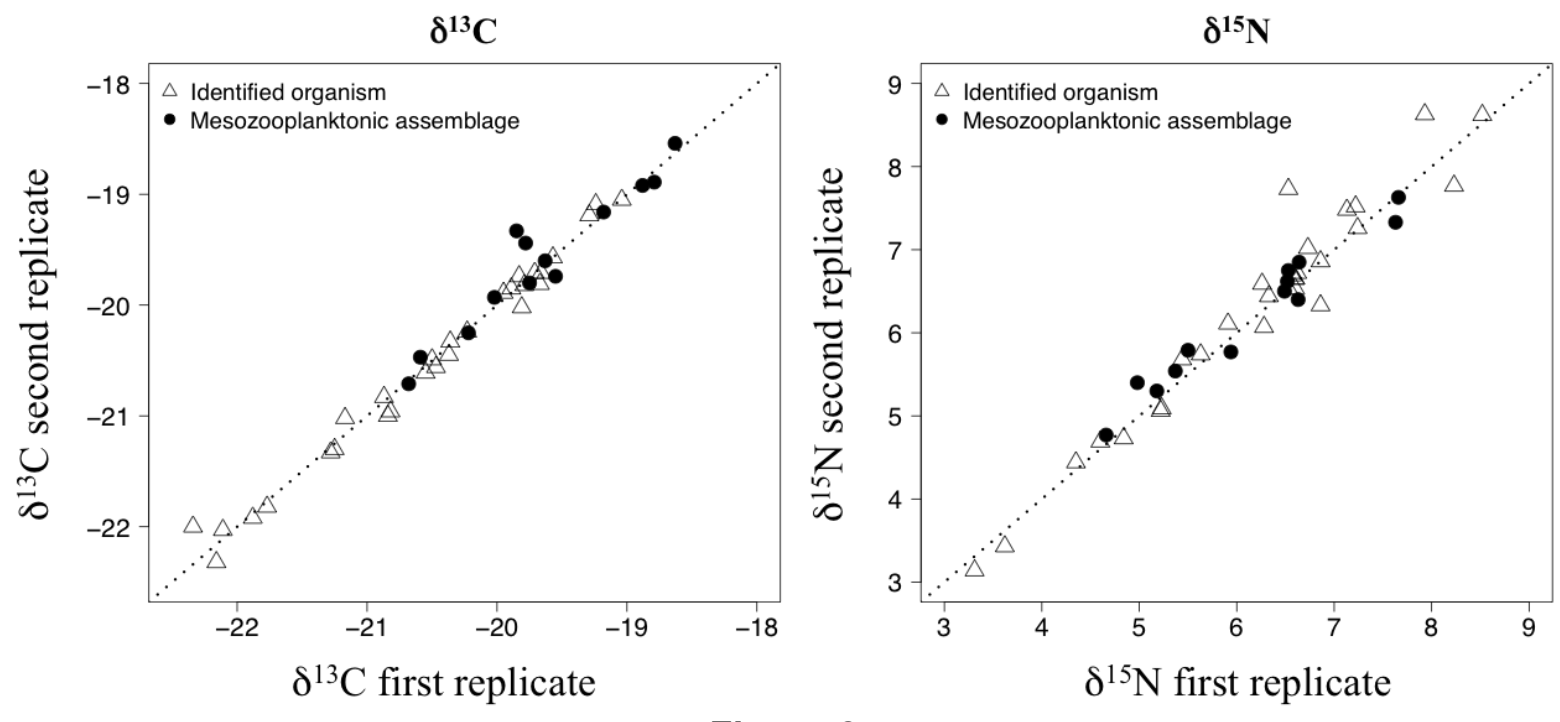

Figure 2 

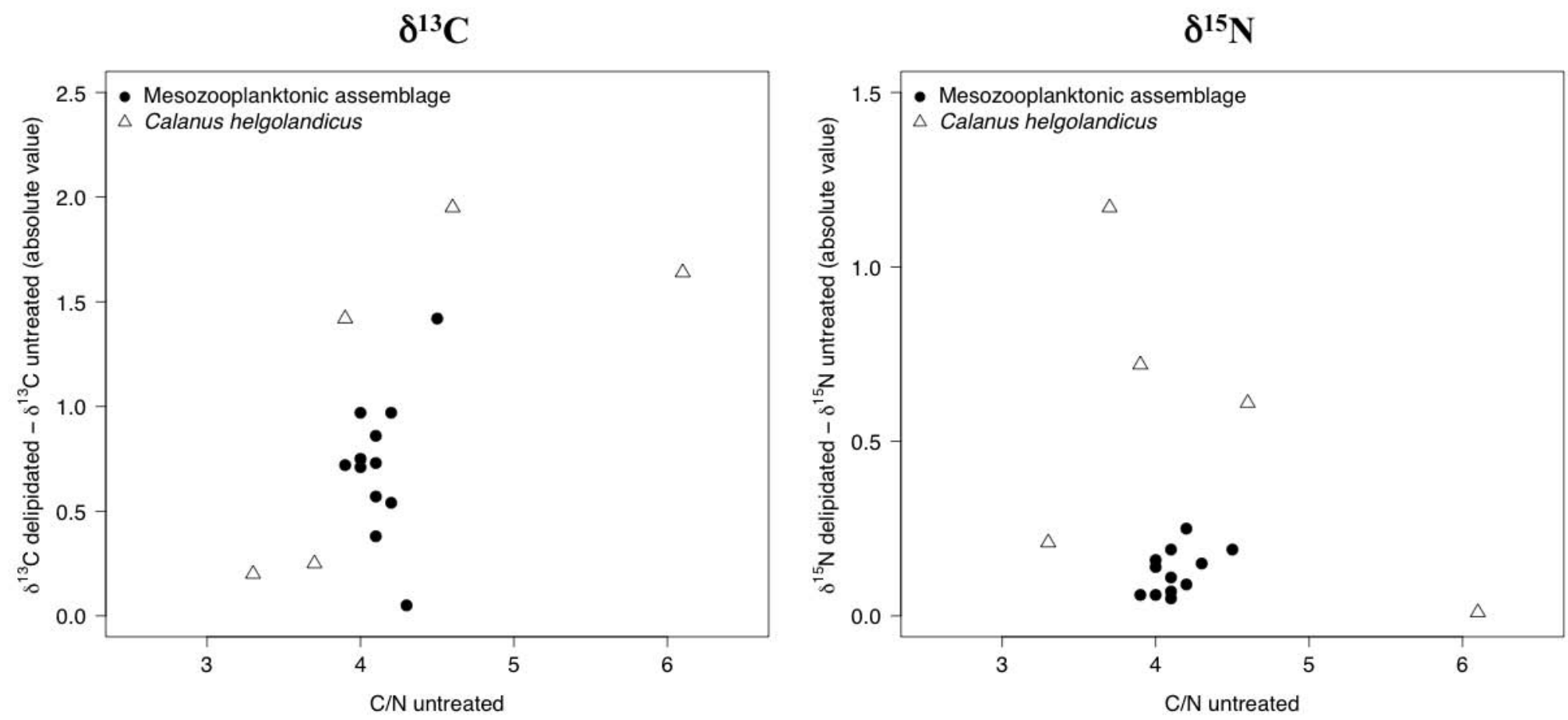

Figure 3 

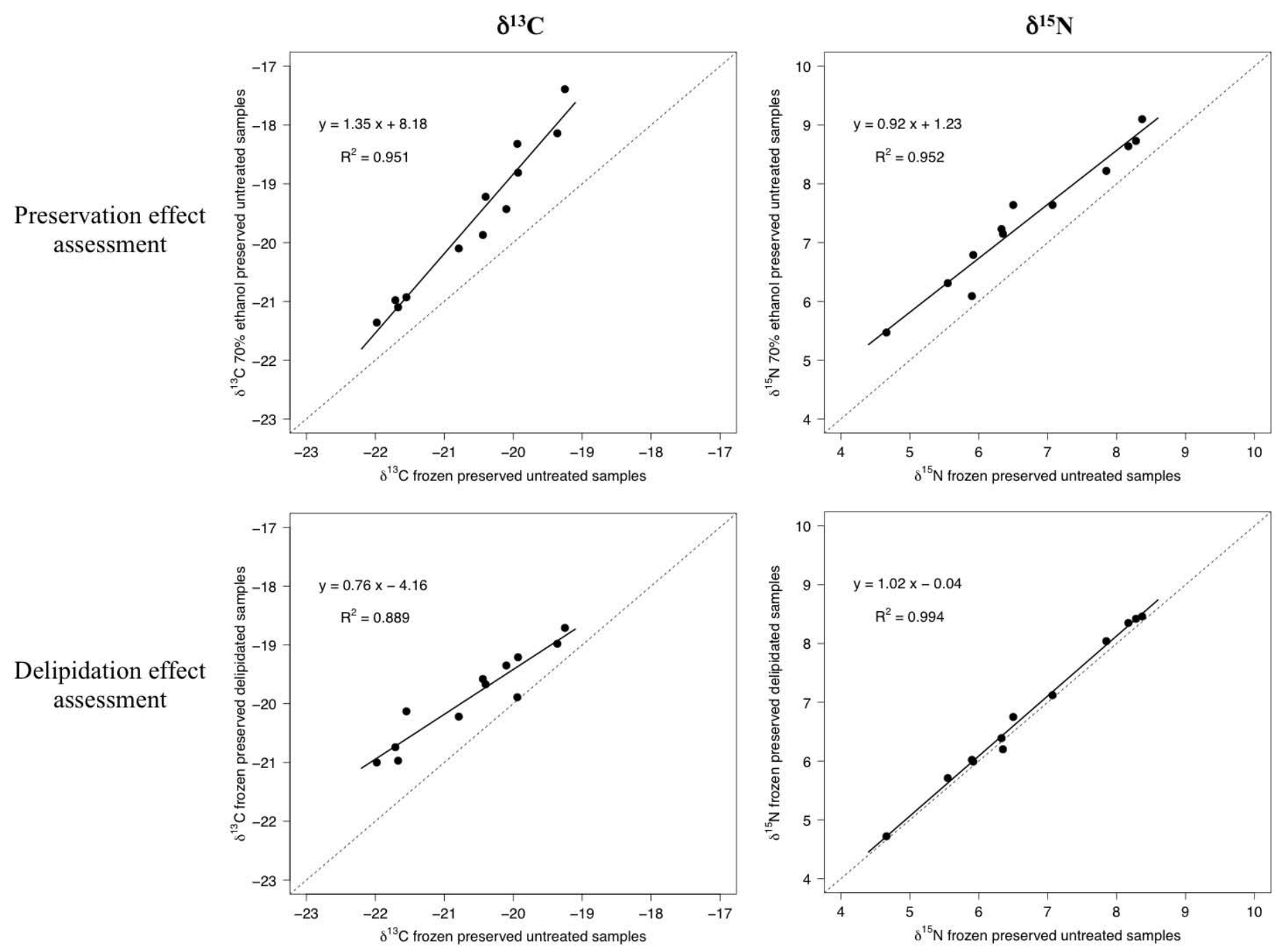

Figure 4 

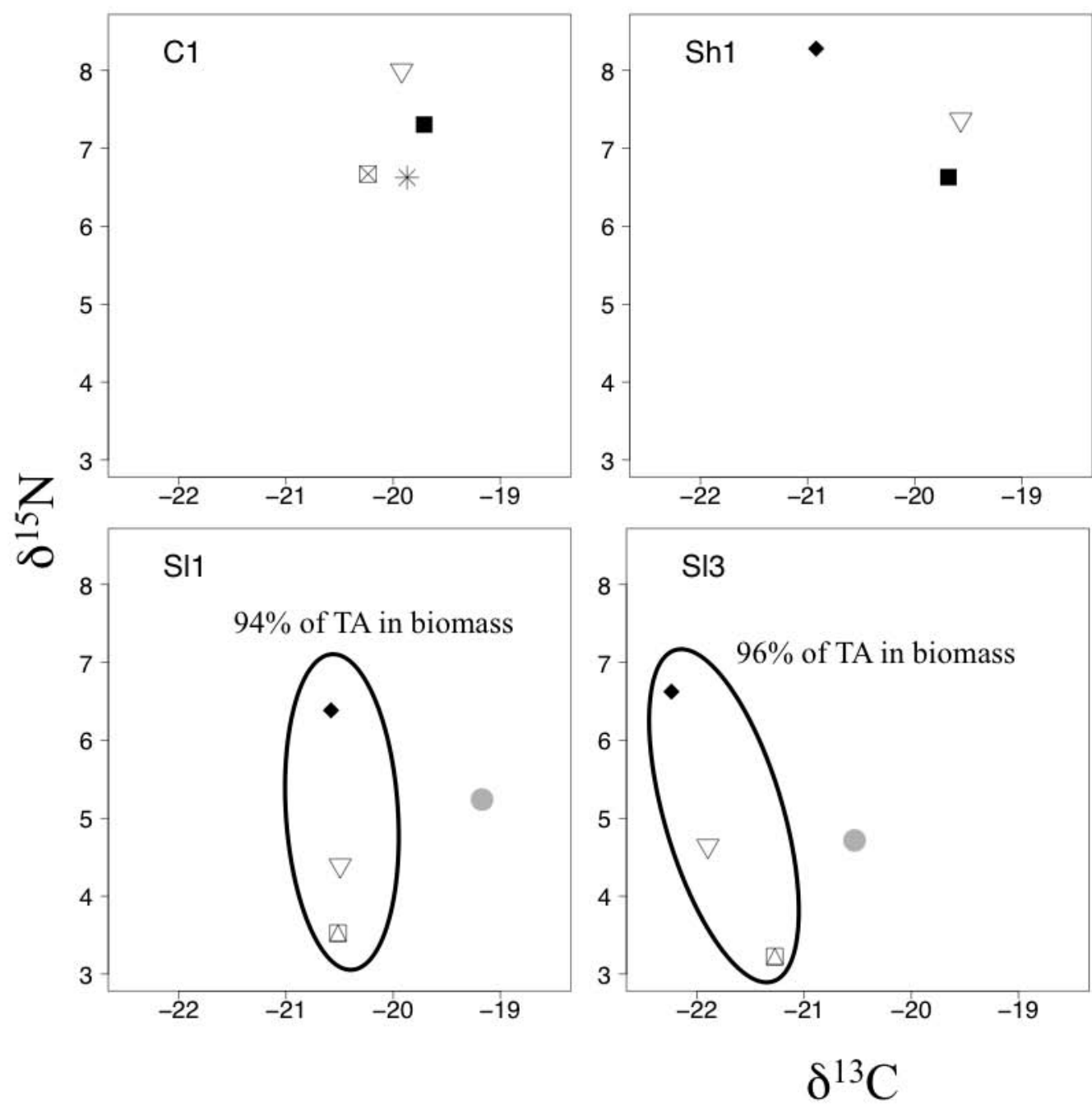

- Undetermined assemblage

- Acartia sp.

- Calanus helgolandicus

* Copepod nauplii

๑ Oithona sp.

- Temora sp.

$\otimes$ Euterpina sp.

$\nabla$ Medium und. Calanoid

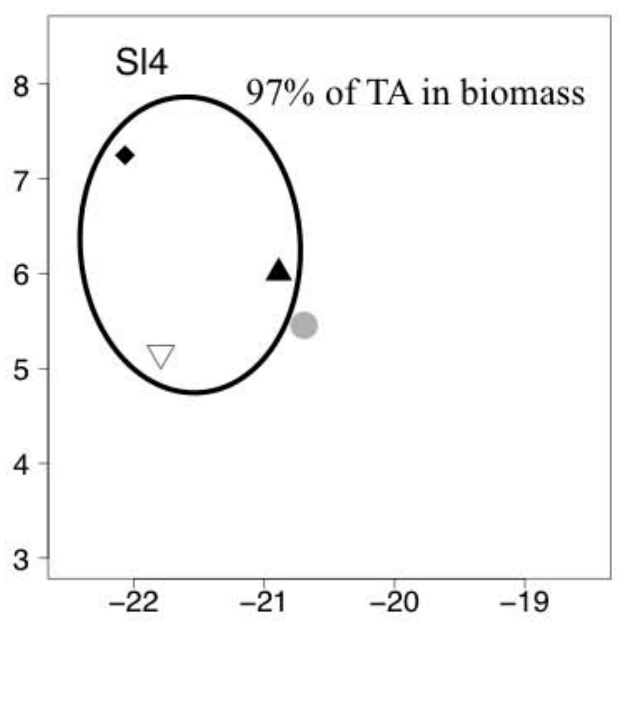

Figure 5 


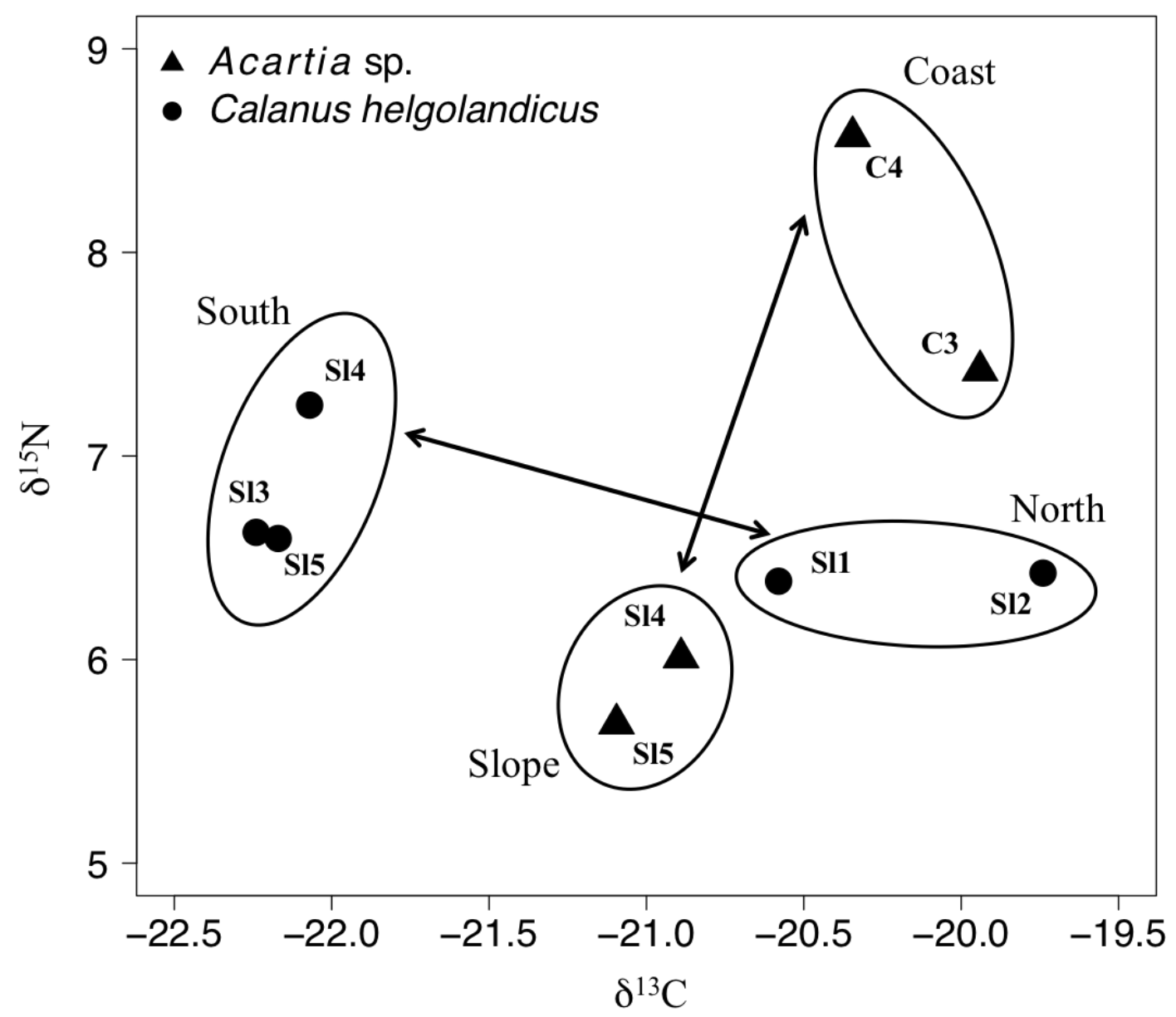

Figure 6 
Height

\section{Mesozooplanktonic prey groups}

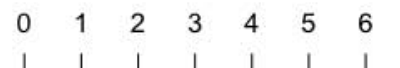

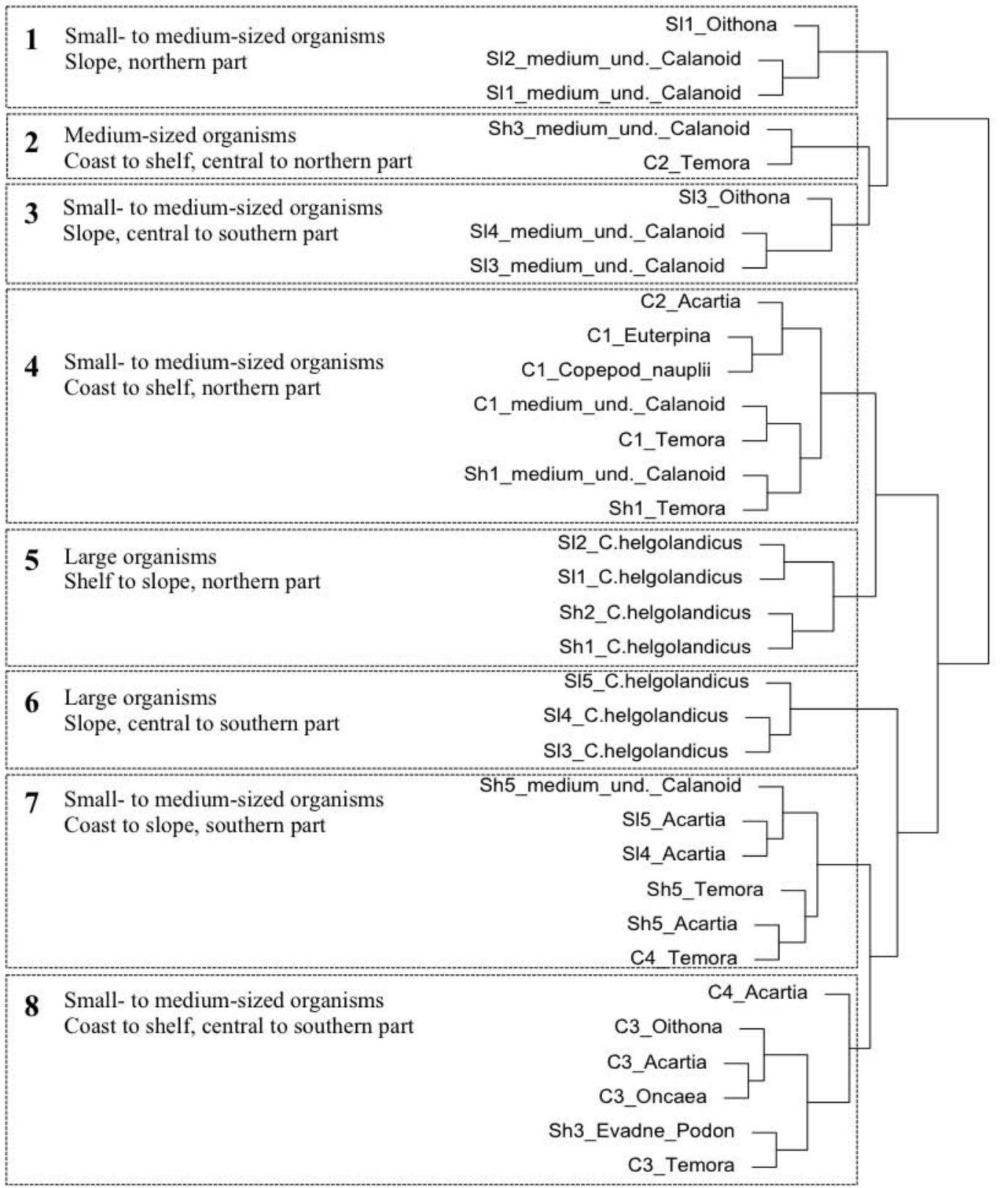

Figure 7 


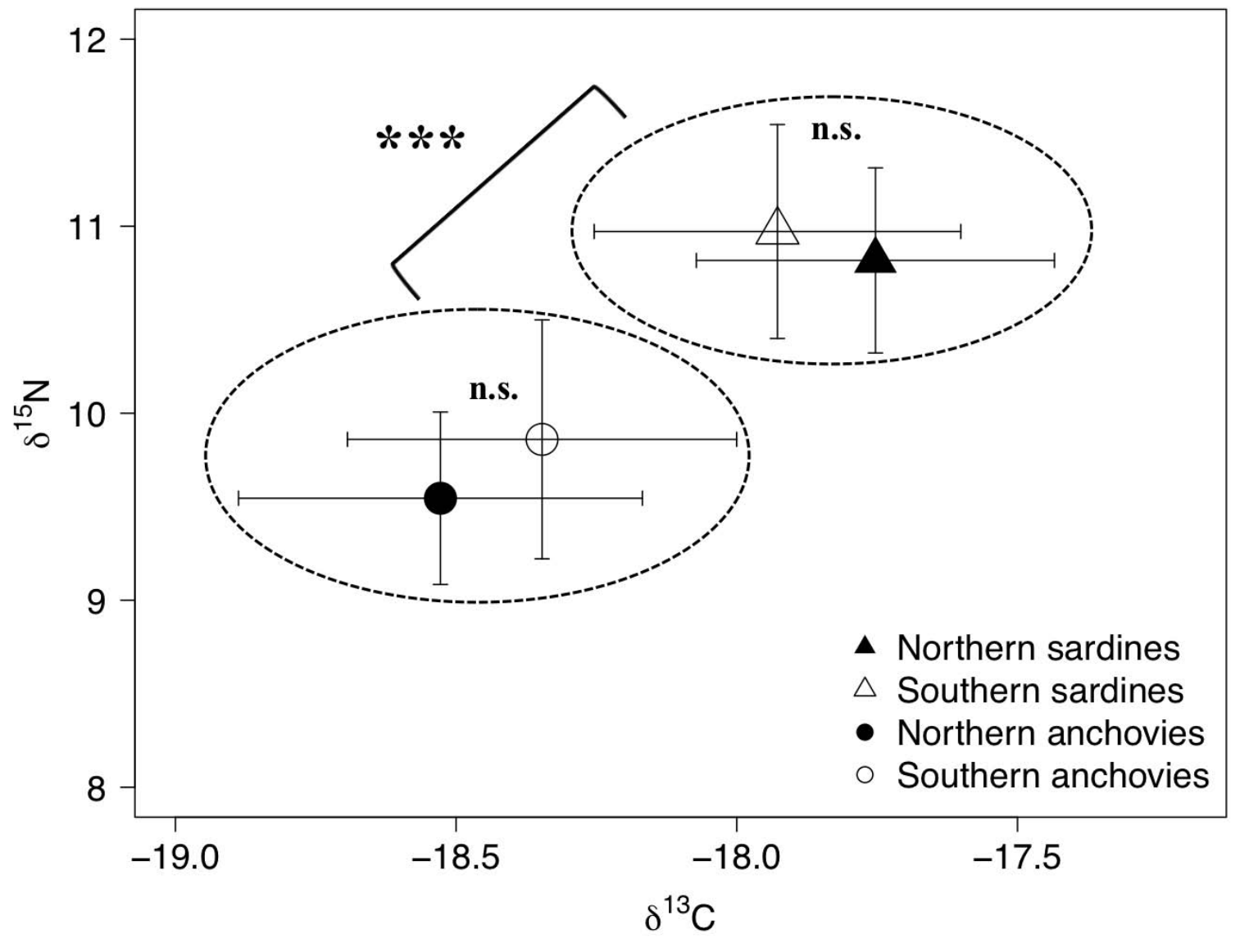

Figure 8 